\title{
Characterization of Fractures and Flow Zones in a Contaminated Shale at the Watervliet Arsenal, Albany County, New York
}

Open-File Report 01-385

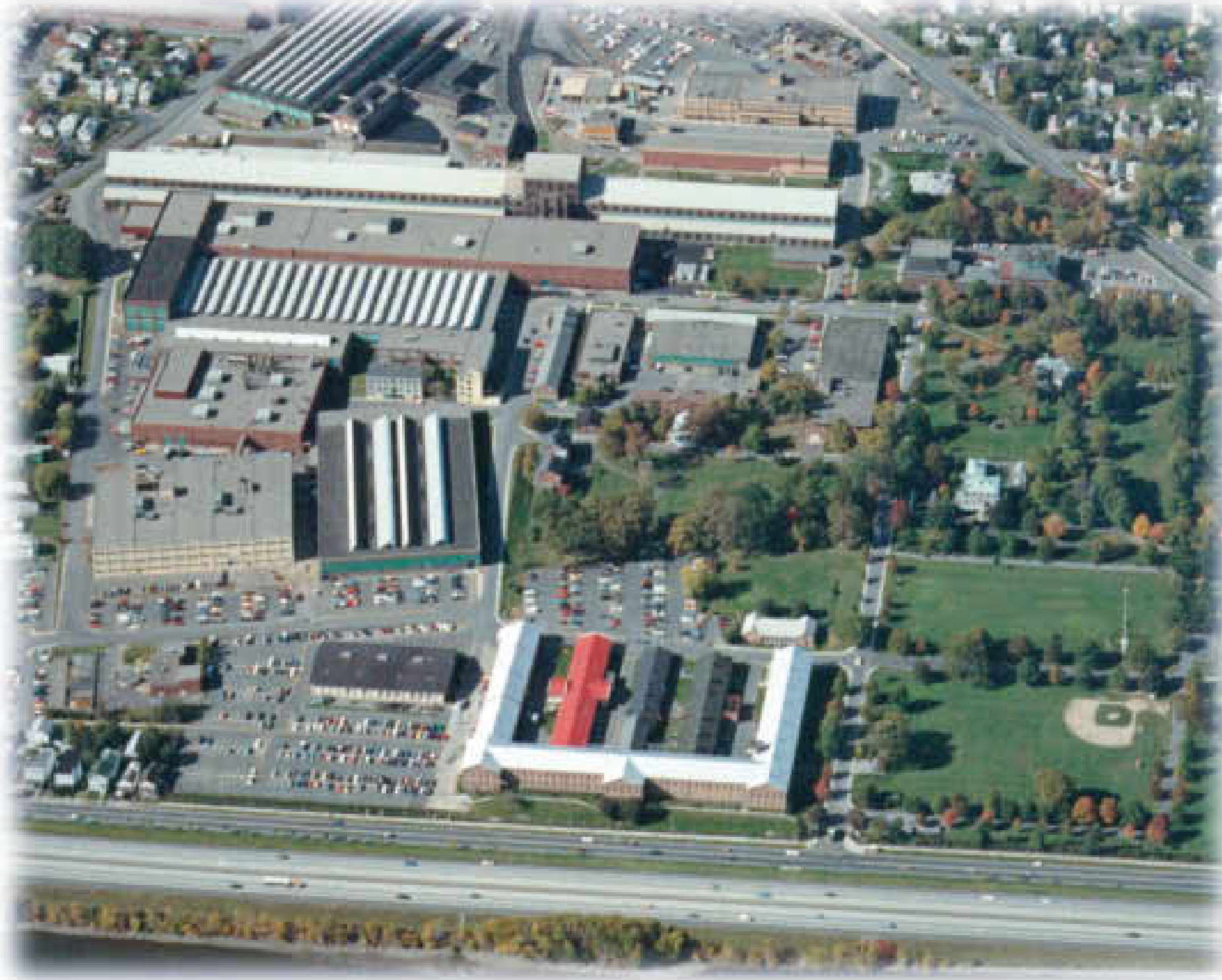

U.S. Department of the Interior U.S. Geological Survey 
This page has been left blank intentionally. 


\section{Characterization of Fractures and Flow Zones in a Contaminated Shale at the Watervliet Arsenal, Albany County, New York}

By John H. Williams and Frederick L. Paillet

U. S. GEOLOGICAL SURVEY

Open-File Report 01-385

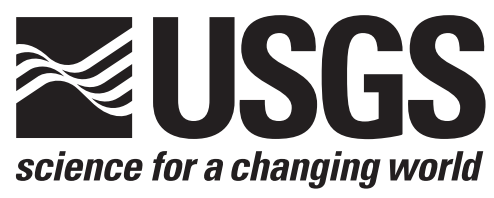

Troy, New York 2002 


\title{
U.S. DEPARTMENT OF THE INTERIOR \\ GAIL A. NORTON, Secretary
}

\author{
U.S. GEOLOGICAL SURVEY
}

Gordon P. Eaton, Director

Any use of trade, product or firm names in this publication is for descriptive purposes only and does not imply endorsement by the U.S. Government

For additional information write to:

District Chief

U.S. Geological Survey

425 Jordan Road

Troy, NY 12180
Copies of this report can be purchased from:

U.S. Geological Survey

Branch of Information Services

Box 25286

Denver, CO 80225-0046 


\section{CONTENTS}

Abstract f...

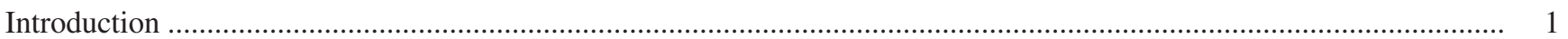

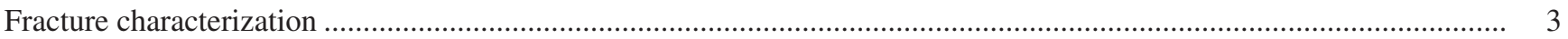

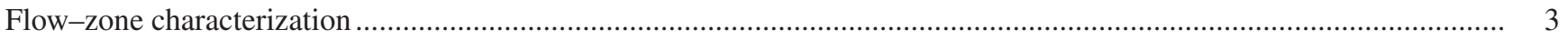

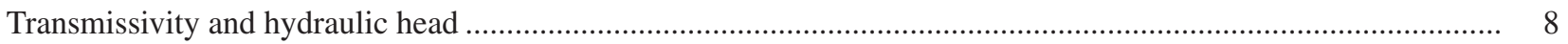

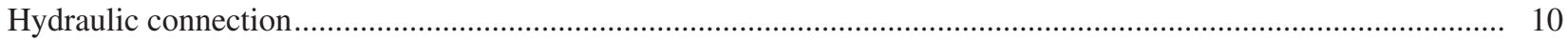

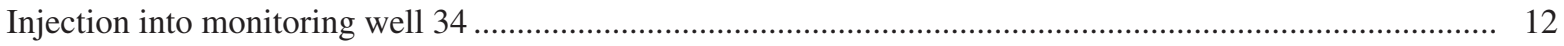

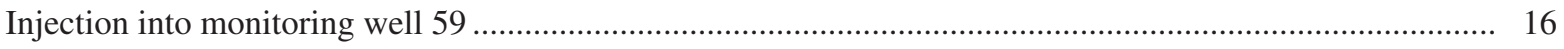

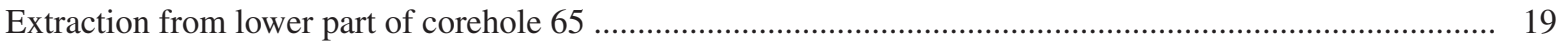

Summary

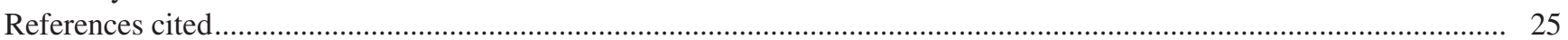

\section{FIGURES}

1. Map showing location of study area at the Watervliet Arsenal, Albany County, NY ................................................ 2

2. Map showing locations of logged and tested monitoring wells and coreholes ......................................................... 4

3. Logs showing acoustic- and optical-televiewer images from monitoring well 34 and analysis for the distribution and orientation of fractures and bedding

4. Logs showing distribution and orientation of fractures and bedding and detected flow zones intersected by the monitoring wells and coreholes

5. Logs showing wellbore diameter, fluid resistivity, temperature, and measured and simulated flow under ambient and injection conditions, transmissivity and hydraulic-head differences of flow zones, and fracture orientation for

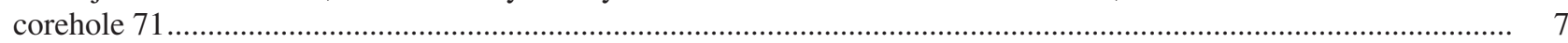

6. Acoustic-televiewer image of fractures in the flow zone at 65 feet at corehole 71 ................................................... 8

7. Three-dimensional representation of fracture-flow zones intersected by the monitoring wells and coreholes ............. 10

8. Sketch showing cross-hole flow test of a single-fracture connection between extraction and observation boreholes and type curve for transient response where flow in the observation borehole is only from wellbore storage ............. 11

9. Sketches showing cross-hole flow tests of fracture connections between extraction and observation boreholes:

A. Isolated and short-circuited fracture connections. B. Type-curve response corresponding to these two extremes, and to three intermediate connections

10. Sketches showing cross-hole flow tests of fracture connections between injection and observation boreholes and corresponding transient type-curve response for: A. A shallow fracture connection inducing flow to a deep fracture in the observation borehole. B. A deep fracture connection inducing flow to a shallow fracture in the observation borehole

11. Sketches showing example of the effects of variations in (A) fracture transmissivity, and (B) fracture storage coefficients on the shape and magnitude of cross-hole flow type curves for the fracture connections depicted in figure $9 \mathrm{~A}$

12. Hydrographs showing water levels in the monitoring wells and coreholes for the cross-hole injection tests:

A. Injection into monitoring well 34. B. Injection into monitoring well 59.

13. Graphs showing measured flow and model type curves for the observation boreholes during the cross-hole tests:

A. Corehole 71 at $50 \mathrm{ft}$ during injection into monitoring well 34. B. Corehole 65 at $60 \mathrm{ft}$ during injection into monitoring well 34. C. Corehole 71 at $50 \mathrm{ft}$ during the injection into monitoring well 59. D. Corehole 65 at $60 \mathrm{ft}$ during injection into monitoring well 59. E. Corehole 71 at $50 \mathrm{ft}$ during extraction from the lower part of corehole 65. F. Corehole 71 at $50 \mathrm{ft}$ during extraction from the upper part of corehole 65

14. Logs showing wellbore diameter, flow, and fluid resistivity for corehole 65 during injection cross-hole tests at monitoring well 34 and 59

15. Hydrographs showing water levels in the monitoring wells and coreholes for the cross-hole extraction tests:

A. Extraction from lower part of corehole 65. B. Extraction from upper part of corehole 65 
16. Hydrograph showing depth to water level in corehole 72 and gage height in the adjacent Hudson River at Albany, April 26 to May 1, 2001

17. Three-dimensional representation of fracture-flow zones intersected by the monitoring wells and coreholes revised based on hydraulic connections

\section{TABLES}

1. Record of logged monitoring wells and coreholes at the Watervliet Arsenal, Albany County, N. Y., $2000-01$.

2. Estimated hydraulic properties of fracture-flow zones detected in the monitoring wells and coreholes at the Watervliet Arsenal, Albany County, N. Y., 2000-01

3. Water levels in the monitoring wells and coreholes for the cross-hole flow tests at the Watervliet Arsenal, Albany County, N. Y., 2000-01

\section{CONVERSION FACTORS, ABBREVIATIONS, AND VERTICAL DATUM}

\begin{tabular}{rcl}
\hline Multiply & By & To obtain \\
\hline & Length & \\
inch(in) & 25.4 & millimeter \\
foot(ft) & 0.3048 & meter \\
& Flow Rate & \\
gallons per minute (gal/min) & 0.06309 & liters per second \\
& Temperature & \\
degrees Fahrenheit & $5 / 9 \times$ x $\left({ }^{\circ} \mathrm{F}-32\right)$ & degrees Celsius \\
& Transmissivity* & \\
foot squared per day & 0.09290 & meter squared per day \\
\hline
\end{tabular}

Sea level: In this report sea level refers to the National Geodetic Vertical Datum of 1929 (NGVD of 1929) a geodetic datum derived from a general adjustment of the first-order level nets of both the United States and Canada, formerly called Sea Level Datum of 1929.

*Transmissivity: The standard unit for transmissivity $(T)$ is cubic foot per day per square foot times foot of aquifer thickness $\left[\left(\mathrm{ft}^{3} / \mathrm{d}\right) / \mathrm{ft}^{2}\right] \mathrm{ft}$. In this report, the mathematically reduced form, foot squared per day ( $\left.\mathrm{ft}{ }^{2} / \mathrm{d}\right)$, is used for convenience. 


\title{
Characterization of Fractures and Flow Zones in a Contaminated Shale at the Watervliet Arsenal, Albany County, New York
}

\author{
By John H. Williams and Frederick L. Paillet
}

\begin{abstract}
Flow zones in a fractured shale in and near a plume of volatile organic compounds at the Watervliet Arsenal in Albany County, N. Y. were characterized through the integrated analysis of geophysical logs and single- and cross-hole flow tests. Information on the fracture-flow network at the site was needed to design an effective groundwater monitoring system, estimate offsite contaminant migration, and evaluate potential containment and remedial actions.
\end{abstract}

Four newly drilled coreholes and four older monitoring wells were logged and tested to define the distribution and orientation of fractures that intersected a combined total of 500 feet of open hole. Analysis of borehole-wall image logs obtained with acoustic and optical televiewers indicated 79 subhorizontal to steeply dipping fractures with a wide range of dip directions. Analysis of fluid resistivity, temperature, and heat-pulse and electromagnetic flowmeter logs obtained under ambient and short-term stressed conditions identified 14 flow zones, which consist of one to several fractures and whose estimated transmissivity values range from 0.1 to more than 250 feet squared per day.

Cross-hole flow tests, which were used to characterize the hydraulic connection between fracture-flow zones intersected by the boreholes, entailed (1) injection into or extraction from boreholes that penetrated a single fracture-flow zone or whose zones were isolated by an inflatable packer, and (2) measurement of the transient response of water levels and flow in surrounding boreholes. Results indicate a wellconnected fracture network with an estimated transmissivity of 80 to 250 feet squared per day that extends for at least 200 feet across the site. This interconnected fracture-flow network greatly affects the hydrology of the site and has important implications for contaminant monitoring and remedial actions.

\section{INTRODUCTION}

Historical use of solvents within the main manufacturing area at the Watervliet Arsenal in Albany County, N. Y. (fig. 1) has resulted in the movement of dense non-aqueous fluids into the underlying bedrock and contamination of ground water with volatile organic compounds. The U.S. Geological Survey, in cooperation with the U. S. Army Corps of Engineers, conducted a study from September 2000 to May 2001 to characterize bedrock fracture-flow zones at the site as a basis for the design of an effective ground-water monitoring system, estimation of contaminant migration offsite, and evaluation of potential containment and remedial actions.

The site is underlain by the Normanskill Formation, a dark-gray shale of Ordovician age. The shale is overlain by 10 to 15 feet of artificial fill, alluvium, and glacial drift. The general direction of ground-water flow is southeastward toward the Hudson River, a regional discharge area.

Advanced borehole geophysical methods were used in the fracture and flow-zone characterization; these included borehole-wall imaging and single- and cross-hole flowmeter analysis. Four newly drilled coreholes and four older monitoring wells in and near 

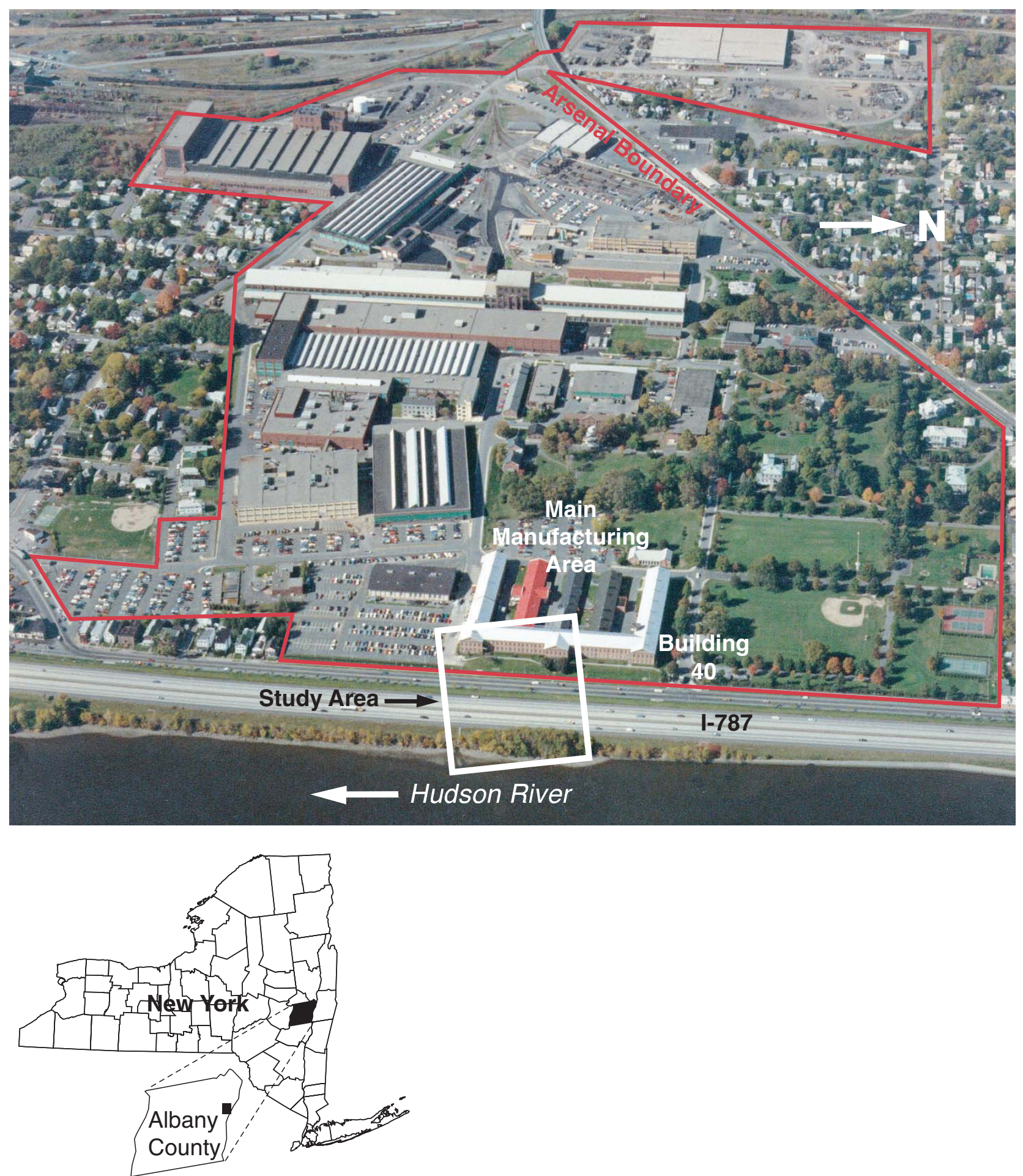

Figure 1. Location of study area at the Watervliet Arsenal, Albany County, N.Y. 
the contamination plume were logged, and four crosshole flow tests were conducted. This report summarizes the results of the geophysical logging and cross-hole testing and describes the fractures and flow zones at the site.

\section{FRACTURE CHARACTERIZATION}

The distribution and orientation of fractures intersected by the four monitoring wells $(34,51,58$, and 59) and four coreholes (65, 68, 71, and 72) (fig. 2 and table 1) were interpreted through the analysis of borehole-wall image logs. Acoustic-televiewer logs were obtained in the open intervals of the wells and coreholes. Optical-televiewer logs were collected in monitoring well 34, the upper part of corehole 65, and corehole 68. Methods of analysis of borehole-wall image logs for fracture characterization is described by Williams and Johnson (2000). Examples of acoustic- and optical- televiewer logs and fracture analysis for a selected interval in monitoring well 34 are presented in figure 3 .

The distribution and orientation of the fractures and bedding features intersected by the monitoring wells and coreholes are depicted in figure 4 . The analysis identified 79 fractures within the total $500 \mathrm{ft}$ of open hole logged in the eight wells and coreholes. The fractures are subhorizontal to steeply dipping and have a wide range of dip directions. Many fractures dip to the east at 50 to 60 degrees parallel to bedding.

\section{FLOW-ZONE CHARACTERIZATION}

The distribution of flow zones intersected by the monitoring wells and coreholes was delineated through an integrated analysis of the borehole-wall image, fluid, and flowmeter logs. Flowmeter logs and fluid resistivity and temperature logs were collected under ambient and short-term stressed conditions. The flowmeter method for identifying flow zones in fractured bedrock is described by Paillet and others (1987). Vertical flow in the monitoring wells was measured under ambient and stressed conditions at selected depth stations with a heat-pulse flowmeter, whose lower detection limit is about 0.005 gallons per minute (gal/min). Vertical flow in the coreholes under ambient and stressed conditions were collected with an electromagnetic flowmeter, whose lower detection limit is about an order of magnitude higher than that of the heat-pulse flowmeter. The electromagnetic flowmeter was used in stationary and trolling (logging) modes. Stationary heat-pulse flowmeter measurements also were made under ambient conditions in coreholes 65,68 , and 71 . The short-term flowmeter stress tests entailed the injection of 3 to $5 \mathrm{gal} / \mathrm{min}$ into the wells and coreholes except at corehole 72 , which was pumped at $2 \mathrm{gal} / \mathrm{min}$. Specific capacities of the wells and coreholes, as calculated from these tests, are presented in table 1.

The flowmeter method detects only flow zones whose transmissivity is within 1.5 to 2 orders of magnitude of the most transmissive zone in the borehole (Paillet, 1998). An example of this type of analysis showing the ambient and stressed fluid

Table 1. Record of logged monitoring wells and coreholes at the Watervliet Arsenal, Albany County, N.Y., 2000-01

[Locations are shown in fig. 2. (Gal/min)/ft, gallons per minute per foot.]

\begin{tabular}{|c|c|c|c|c|c|c|c|}
\hline Sitenumber & $\begin{array}{l}\text { USGS } \\
\text { county } \\
\text { number }\end{array}$ & $\begin{array}{l}\text { Land-surface } \\
\text { elevation, } \\
\text { in feet }\end{array}$ & $\begin{array}{l}\text { Hole } \\
\text { depth, } \\
\text { in feet }\end{array}$ & $\begin{array}{l}\text { Casing } \\
\text { depth, } \\
\text { in feet }\end{array}$ & Date logged & $\begin{array}{l}\text { Depth to water, } \\
\text { in feet }\end{array}$ & $\begin{array}{l}\text { Specific capacity, } \\
\text { in }(\mathrm{gal} / \mathrm{min}) / \mathrm{ft}\end{array}$ \\
\hline \multicolumn{8}{|c|}{ Monitoring well } \\
\hline 34 & A 656 & 18.56 & 31.5 & 16.5 & $9 / 14 / 00$ & 9.55 & 1.2 \\
\hline 51 & A 657 & 18.71 & 71 & 52.5 & $9 / 14 / 00$ & 10.00 & none detected \\
\hline 58 & A 654 & 20.54 & 82 & 64 & $9 / 14 / 00$ & 10.74 & 0.002 \\
\hline 59 & А 659 & 20.17 & 96 & 75 & $9 / 14 / 00$ & 10.92 & 1.0 \\
\hline \multicolumn{8}{|l|}{ Corehole } \\
\hline 65 & A 655 & 18.69 & 165 & 21 & $12 / 1 / 00$ & 9.24 & 1.3 \\
\hline 68 & A 652 & 21.41 & 75 & 17.5 & $12 / 22 / 00$ & 7.85 & 0.72 \\
\hline 71 & A 658 & 20.69 & 105 & 21 & $12 / 14 / 00$ & 9.60 & 1.1 \\
\hline 72 & A 660 & 17.23 & 125 & 22 & $4 / 24 / 01$ & 11.01 & 0.32 \\
\hline
\end{tabular}




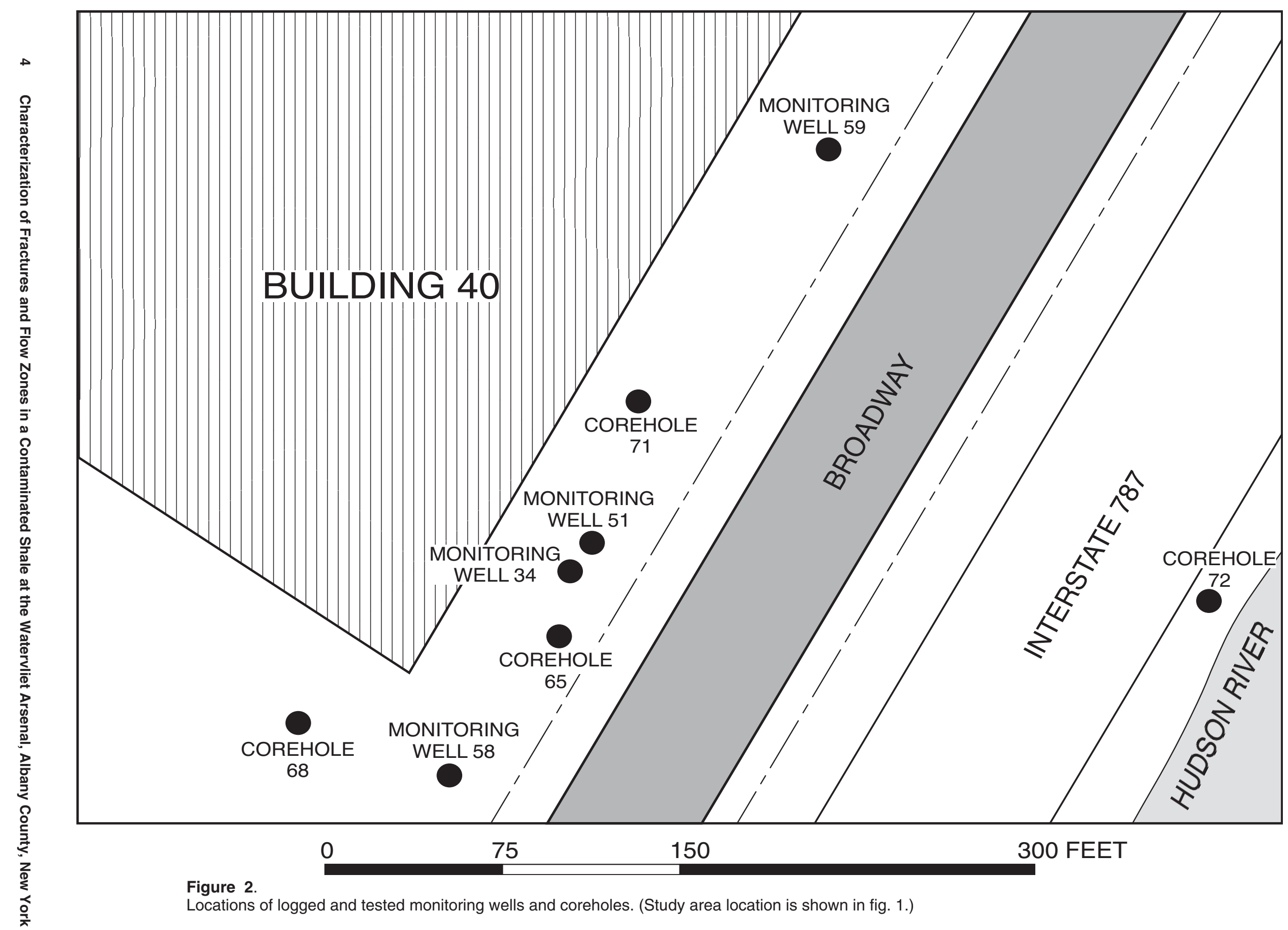




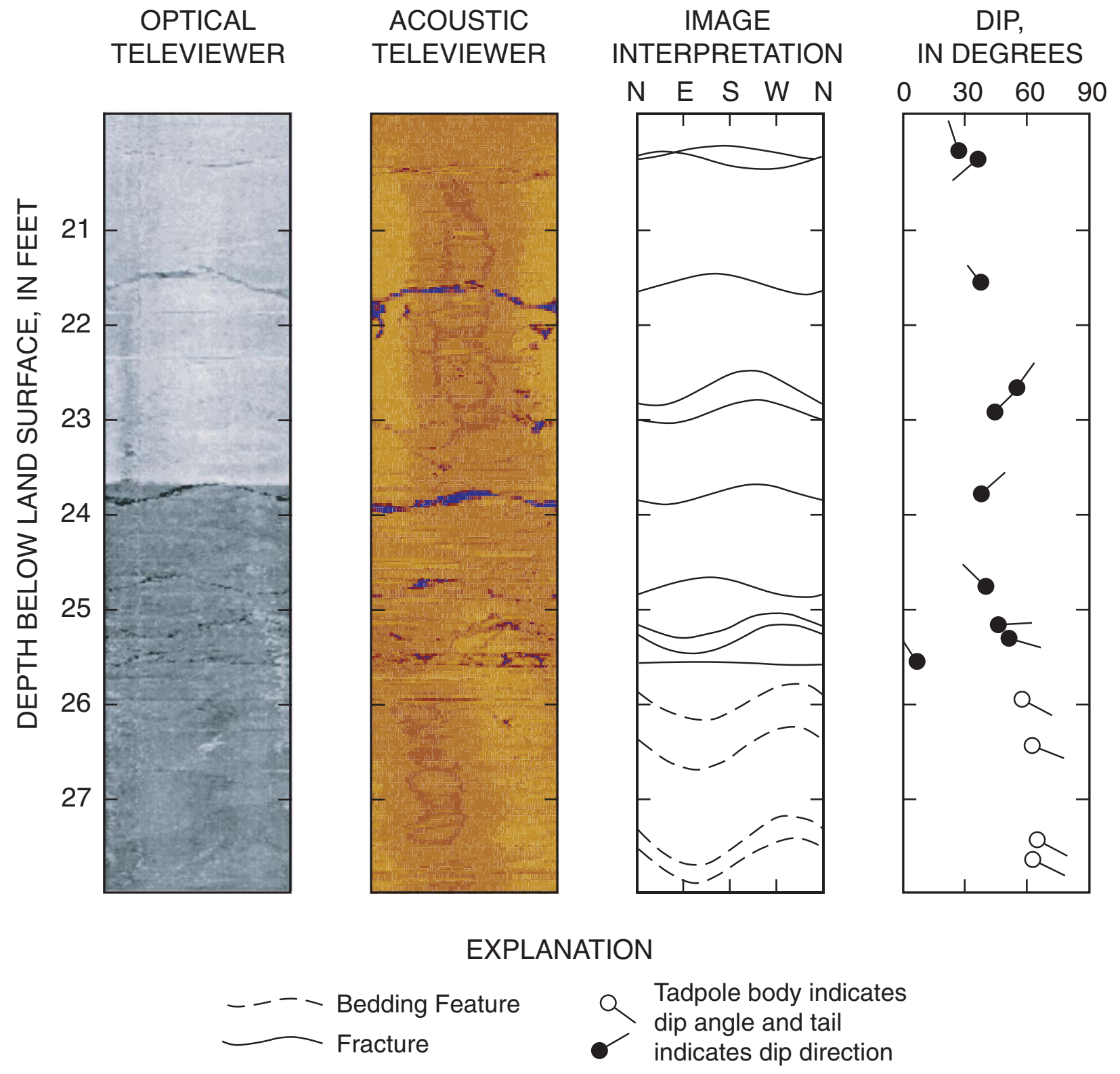

Figure 3. Acoustic- and optical-televiewer images from monitoring well 34 and analysis for the distribution and orientation of fractures and bedding. (Location is shown in fig. 2.) 


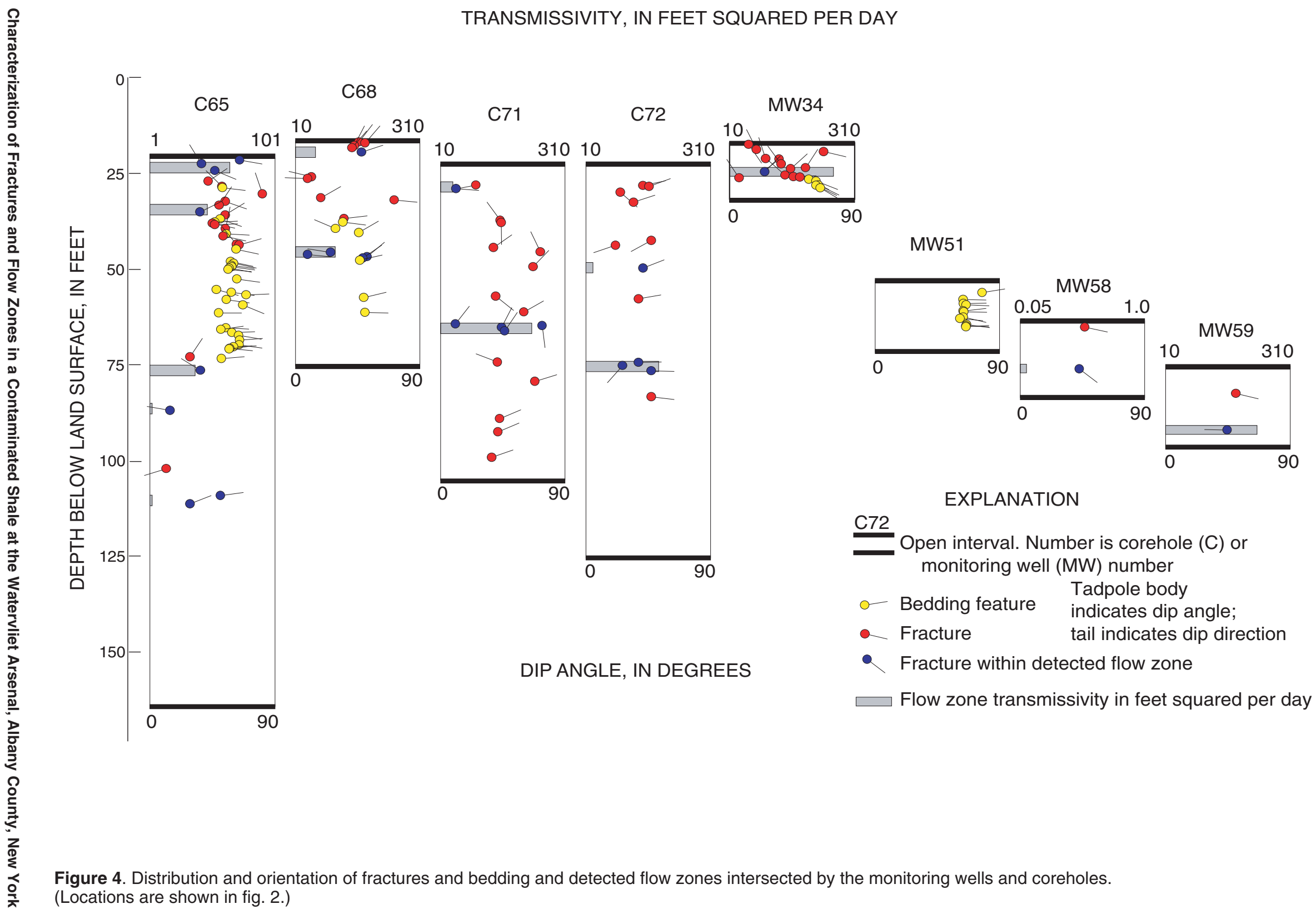




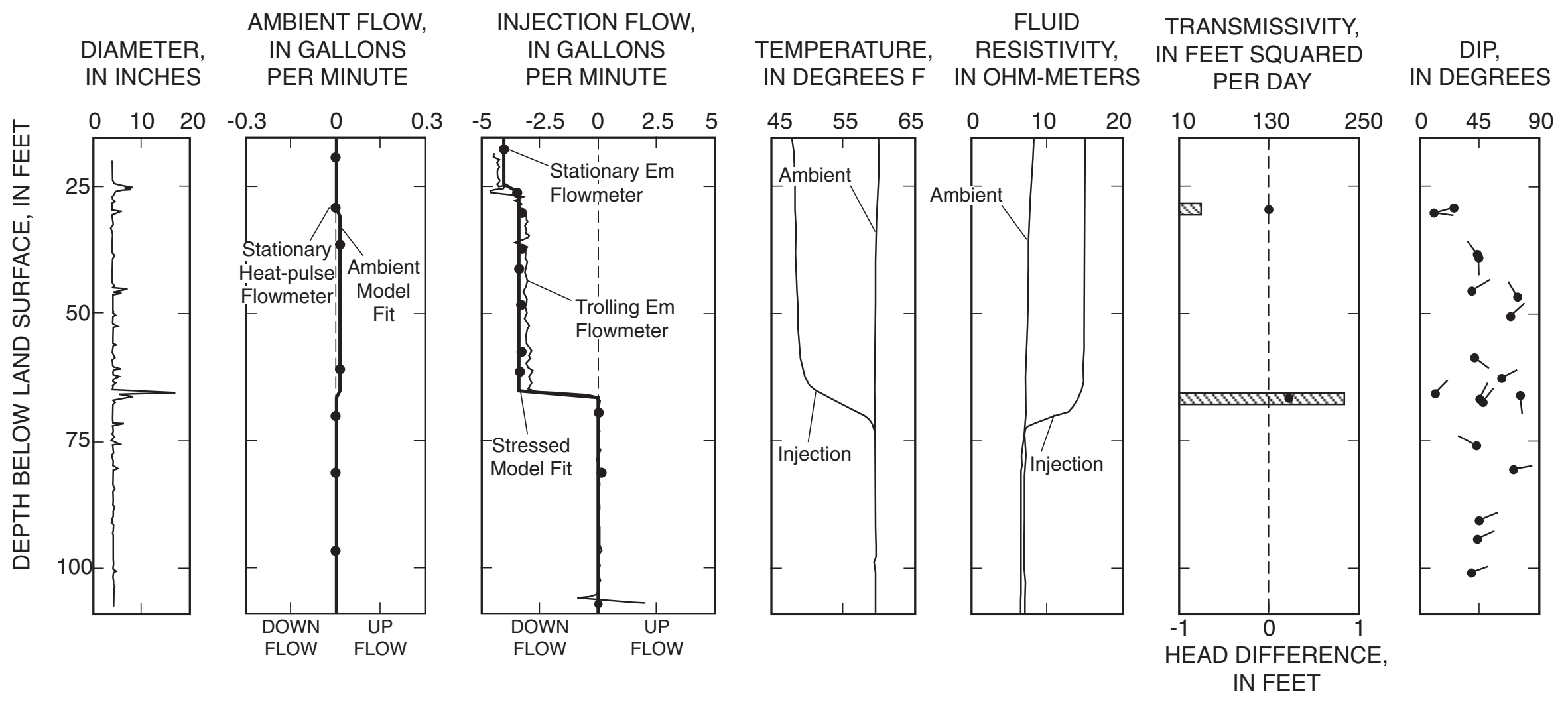

Figure 5. Wellbore diameter, fluid resistivity, temperature, and measured and simulated flow under ambient and injection conditions, transmissivity and hydraulic-head differences of flow zones, and fracture orientation for corehole 71. (Location is shown in fig. 2.) 


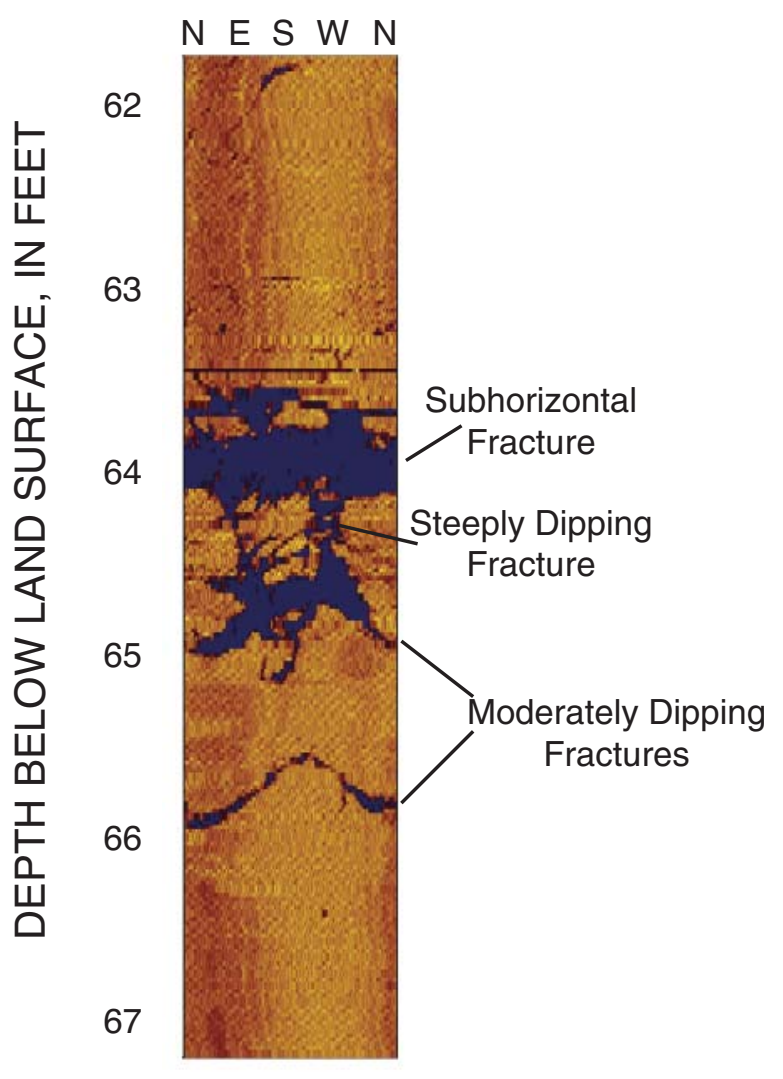

Figure 6. Acoustic-televiewer image of fractures in the flow zone at 65 feet at corehole 71. (Location is shown in fig. 2.)

resistivity, temperature, and flowmeter logs, and a delineation of flow zones in corehole 71 is presented in figure 5. The acoustic-televiewer image of the fractures within the flow zone at $65 \mathrm{ft}$ in corehole 71 is presented in figure 6 . The 65 -ft flow zone consists of a large subhorizontal fracture, two moderately dipping fractures, and a steeply dipping fracture.

The distribution of detected flow zones intersected by the monitoring wells and coreholes is presented in figure 4 and table 2. Fourteen flow zones consisting of one to several fractures were detected in the total $500 \mathrm{ft}$ of open hole logged in the eight wells and coreholes. Single-flow zones were detected in monitoring wells 34,58 , and 59; two flow zones were detected in each of coreholes 68,71 , and 72 ; five flow zones were detected in corehole 65 ; and no flow zones were detected in monitoring well 51.

A three-dimensional representation of the transmissive fractures intersected by the wells and coreholes is shown in figure 7. The representation is based on a simple radial projection of the fractures within the detected flow zones. The fractures are projected a radial distance of $50 \mathrm{ft}$ according to their orientation measured at the borehole wall. Multiple fractures that have similar orientations within the same flow zone are displayed as a single combined feature.

\section{TRANSMISIVITY AND HYDRAULIC HEAD}

The transmissivity and hydraulic head of the flow zones intersected by the monitoring wells and coreholes were estimated by flowmeter model analysis as described by Paillet (2000). In this method, measured ambient and stressed flows are matched to simulated flows by trial-and-error adjustment of flowzone transmissivity and head. An example of the results from this type of analysis, depicting measured and simulated flow and estimated transmissivity and hydraulic-head differences of flow zones intersected by corehole 71, is shown in figure 5 .

Estimated transmissivity $(T)$ values for the fracture-flow zones range from 0.1 to 260 feet squared per day ( $\mathrm{ft}^{2} / \mathrm{d}$ ) (fig. 4 and table 2); the highest of these estimates, 230 to $260 \mathrm{ft}^{2} / \mathrm{d}$, are for zones penetrated by monitoring wells 34 and 59 and corehole 71. Lower values were estimated for coreholes 65,68 , and 72 , these range from 3 to $110 \mathrm{ft}^{2} / \mathrm{d}$. The $T$ value of the flow zone penetrated by monitoring well 58 is an order of magnitude lower than all other estimates.

Upward ambient flow from lower to upper fracture zones was measured in coreholes 65,68 , and 71. The smaller estimated hydraulic-head differences as estimated by the flowmeter analysis between zones in coreholes 65 and 71 than between zones in corehole 68 suggest a greater vertical connection between fractures near coreholes 65 and 71 than near corehole 68 (table 2).

Ambient hydraulic head in fractures intersected by monitoring wells 34 and 59 and coreholes 65 and 71 were similar (8.94 to $9.16 \mathrm{ft}$ ); the highest among these heads were in the fracture at monitoring well 59, the lower fractures at corehole 71, and the lower fractures at corehole 65 . The head in the fracture at monitoring well 58 was about $0.5 \mathrm{ft}$ higher than these heads. The heads in the fractures intersected by corehole 68 are about $3 \mathrm{ft}$ higher than in most of the other fractures. The heads in fractures at corehole 72 , nearest to the river, were about $2.5 \mathrm{ft}$ lower than at most of the other boreholes. 
Table 2. Estimated hydraulic properties of fracture-flow zones detected in the monitoring wells and coreholes at the Watervliet Arsenal, Albany County, N.Y., 2000-01.

[Locations are shown in fig. 2. Dashes indicate not determined. Multiple entries for zone depth indicate that the zones were grouped together for the cross-hole flow test.]

\begin{tabular}{|c|c|c|c|c|c|c|c|}
\hline \multirow{2}{*}{$\begin{array}{c}\text { Well or } \\
\text { corehole } \\
\text { no. }\end{array}$} & \multirow{2}{*}{$\begin{array}{l}\text { Zone } \\
\text { depth, } \\
\text { in feet }\end{array}$} & \multirow{2}{*}{$\begin{array}{l}\text { Zone head } \\
\text { elevation, } \\
\text { in feet }\end{array}$} & \multicolumn{2}{|c|}{$\begin{array}{c}\text { Transmissivity, } \\
\text { in feet squared per day }\end{array}$} & \multirow[b]{2}{*}{ Storage } & \multicolumn{2}{|c|}{ Hydraulic connection } \\
\hline & & & $\begin{array}{c}\text { Single- } \\
\text { borehole }\end{array}$ & Cross-hole & & $\begin{array}{c}\text { Well or } \\
\text { corehole no. }\end{array}$ & $\begin{array}{c}\text { Zone depth, } \\
\text { in feet }\end{array}$ \\
\hline 34 & 25 & 8.98 & 260 & 150 & $5 \times 10^{-5}$ & 71 & 65 \\
\hline 34 & 25 & 8.98 & 260 & 100 & $5 \times 10^{-5}$ & 65 & 24 and 35 \\
\hline 51 & - & 8.97 & - & - & - & - & - \\
\hline 58 & 76 & 9.6 & 0.1 & - & - & - & - \\
\hline 59 & 92 & 9.16 & 230 & 230 & $5 \times 10^{-5}$ & 71 & 65 \\
\hline 59 & 92 & 9.16 & 230 & 250 & $1 \times 10^{-5}$ & 65 & 24 and 35 \\
\hline 65 & $\begin{array}{l}24 \\
35\end{array}$ & 8.94 & $\begin{array}{l}65 \\
47\end{array}$ & 100 & $5 \times 10^{-5}$ & 34 & 25 \\
\hline 65 & $\begin{array}{l}24 \\
35\end{array}$ & 8.94 & $\begin{array}{l}65 \\
47\end{array}$ & 100 & $1 \times 10^{-5}$ & 59 & 92 \\
\hline 65 & $\begin{array}{l}24 \\
35\end{array}$ & 8.94 & $\begin{array}{l}65 \\
47\end{array}$ & 100 & $1 \times 10-5$ & 71 & 65 \\
\hline 65 & $\begin{array}{r}78 \\
88 \\
110\end{array}$ & 9.10 & $\begin{array}{r}37 \\
3 \\
3\end{array}$ & 80 & $1 \times 10^{-4}$ & 71 & 65 \\
\hline 68 & 19 & 12.04 & 58 & - & - & - & - \\
\hline 68 & 45 & 12.79 & 110 & - & - & - & - \\
\hline 71 & 28 & 8.92 & 40 & - & - & - & - \\
\hline 71 & 65 & 9.02 & 230 & 230 & $5 \times 10^{-6}$ & 59 & 92 \\
\hline 71 & 65 & 9.02 & 230 & 150 & $5 \times 10^{-6}$ & 34 & 25 \\
\hline 71 & 65 & 9.02 & 230 & 100 & $1 \times 10^{-5}$ & 65 & 24 and 35 \\
\hline 71 & 65 & 9.02 & 230 & 80 & $1 \times 10^{-4}$ & 65 & 78,88 , and 110 \\
\hline 72 & 49 & 6.5 & 7 & - & - & - & - \\
\hline 72 & 75 & 6.5 & 59 & - & - & - & - \\
\hline
\end{tabular}




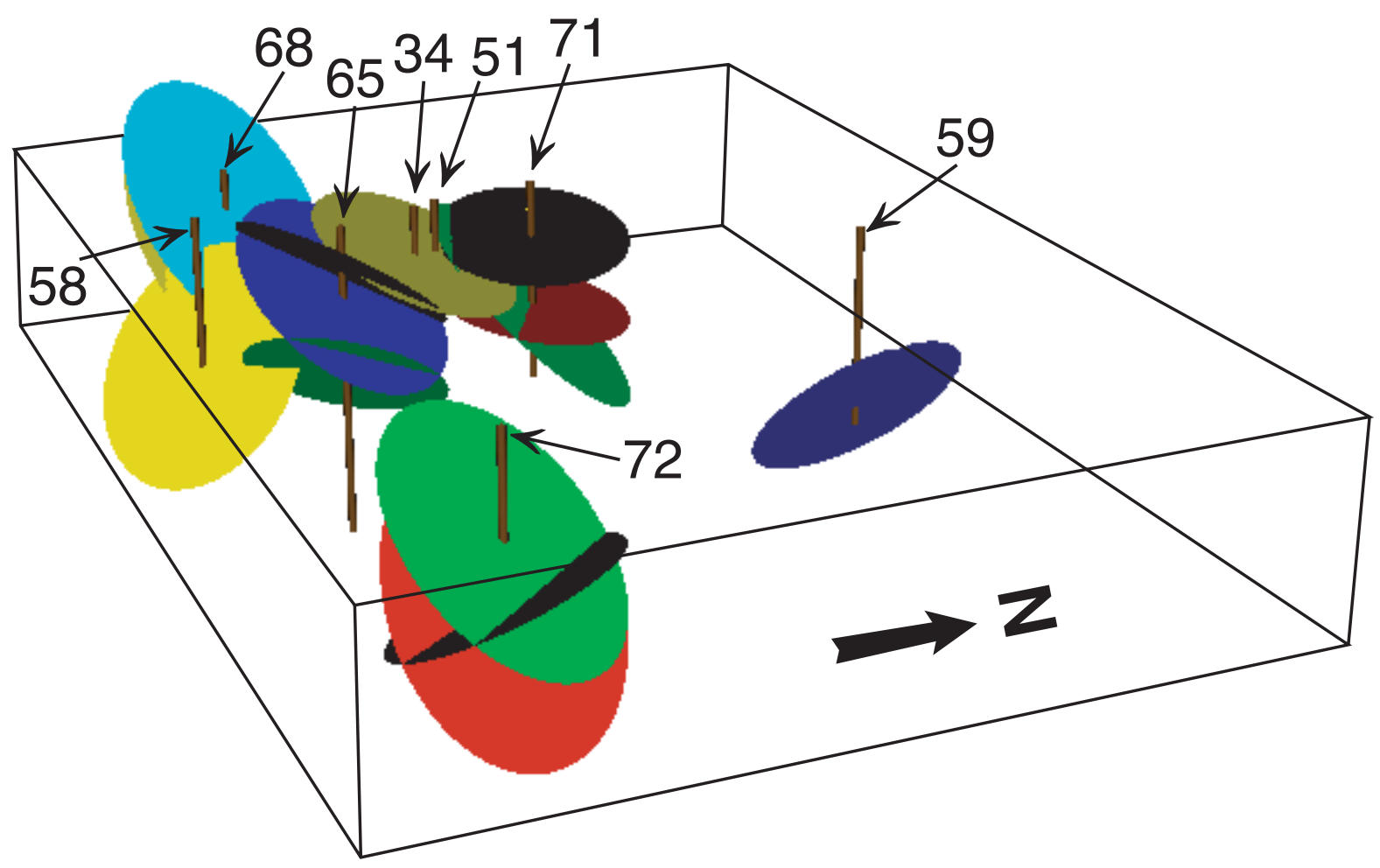

Figure 7. Three-dimensional representation of fracture-flow zones intersected by the monitoring wells and coreholes. (Locations are shown in fig. 2.)

\section{HYDRAULIC CONNECTION}

The hydraulic connection between flow zones intersected by the monitoring wells and coreholes was characterized through an analysis of cross-hole flow tests as described by Paillet (1998). When a borehole that intersects one or more permeable fractures is stressed, the water-level effect extends outward along the fracture network. The generally differing water-level response among individual fractures induces a time-varying flow in an adjacent observation borehole between depths where fractures intersect that borehole. The water-level response also will cause water to flow from or into storage in the observation wellbore. Thus, if flow is measured at a depth station between or above the depth where such fractures intersect the observation borehole, the transient response to the stress can be recorded. This transient flow can be compared to model type curves representative of various fracture connection configurations that may be present between the boreholes. Once a specific type curve is recognized, the model's $T$ and storage coefficient $(S)$ values can be adjusted until the simulation matches the measured response.

Although cross-hole flow tests provide a method to characterize the connections between fractures near pairs of boreholes, a given set of transient-flow data cannot be uniquely interpreted; that is, several different hydraulic connections might result in similar transient responses to a stress. The analysis can be simplified by stressing a borehole that intersects a single, permeable fracture zone to ensure that the water-level response produced by the stress is known to affect that zone only. If the stress induces flow in the observation borehole, that borehole's fracture zone that is most directly connected to the stressed borehole will be the outflow or inflow zone. The flow from or into this zone will vary over time, depending on the connections with other fractures and by movement of water from or into wellbore storage. The transient-flow type curve for the simplest configuration-where the stressed and observation boreholes are connected by a single fracture and flow in the observation borehole is from wellbore storage-is shown in figure 8 . 

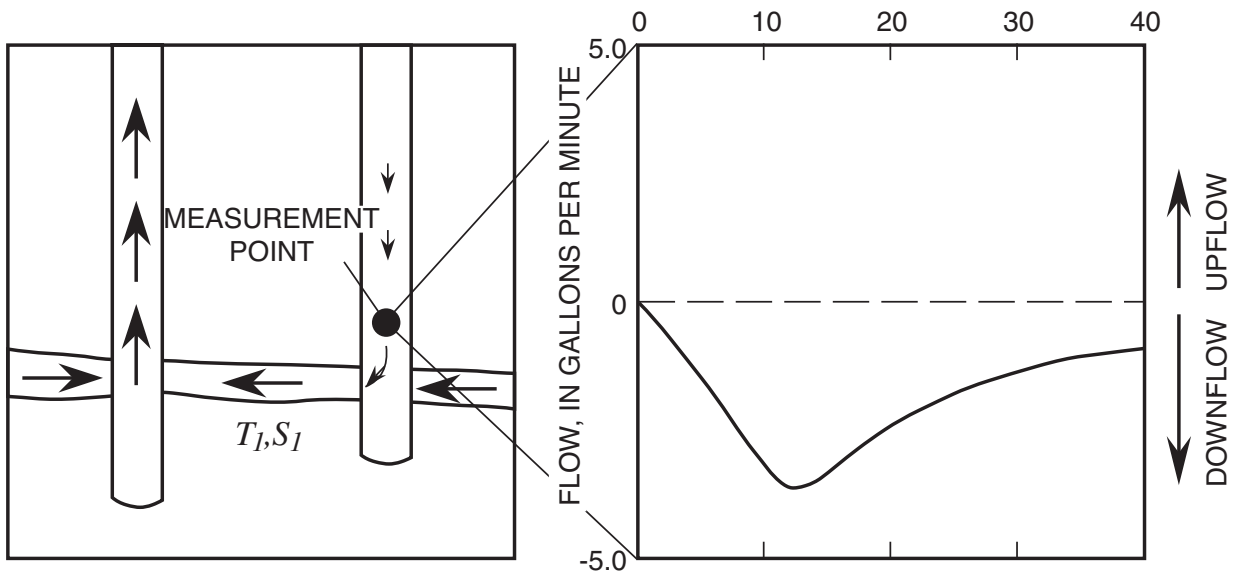

Figure 8. Cross-hole flow test of a single-fracture connection showing direction and relative amount of flow between extraction and observation boreholes and type curve for transient response where flow in the observation borehole is only from wellbore storage.

A

ISOLATED FRACTURES

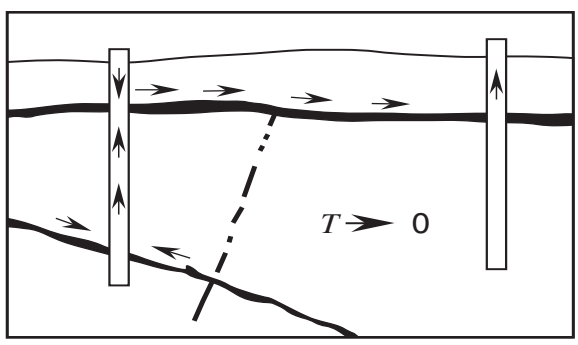

SHORT-CIRCUITED FRACTURES

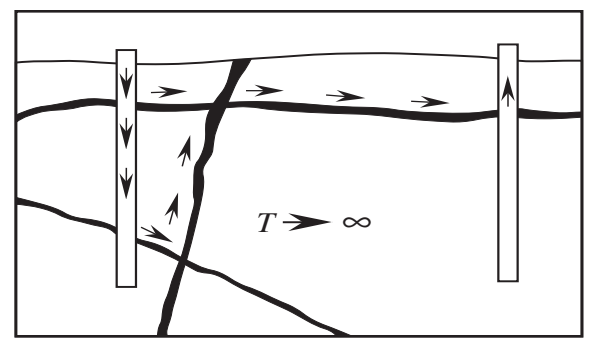

B

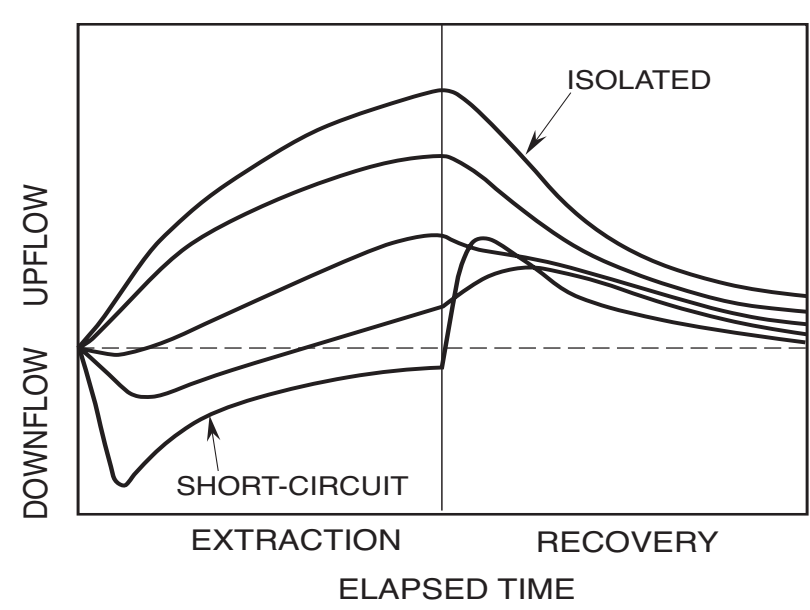

Figure 9. Cross-hole flow tests of fracture connections between extraction and observation boreholes: A. Isolated configuration where the transmissivity of the fracture connection approaches zero; and short-circuited configuration where the transmissivity of the fracture connection approaches infinity. B. Type-curve response corresponding to these two extremes, and to three intermediate connections. 
The transient flow that develops in an observation borehole with two fracture zones in response to extraction is illustrated in figure 9. Flow between the fracture zones varies between two extreme configurations (fig. 9A). One extreme represents no hydraulic connection between the two fracture zones, other than the observation borehole. Here, the applied stress induces upflow from the lower zone into the upper zone, and this upflow increases continuously with time. When the stress ends, the upflow simply decays away (fig. 9B). At the other extreme, fractures in the area between boreholes provide a short circuit between the upper and lower zones. Here, the stress induces a transient downflow that fades away with time. The recovery induces a similar upflow response. In general, where the fracture connection has some finite $T$ value, the flow response will lie somewhere between the two extremes.

The relative $T$ value of the fracture zones in an observation borehole affects the transient flow response. The injection and recovery response for the short-circuited and isolated configurations where the fracture zones have equal $T$ values, and where they differ by an order of magnitude is depicted in figure 10 .

As presented earlier, single-hole flowmeter tests can provide estimated $T$ values for fracture zones. Those $T$ values can be used to determine the $S$ values that give the best model fit to the cross-hole flow data. In general, the magnitude of the fracture-zone's $T$ value determines how quickly the transient flow increases in response to the stress (fig. 11A). Commonly, the response time in the transient flow will simply confirm the $T$ estimates given by the single-hole tests, although differences can occur because the cross-borehole test data apply to the area between boreholes, rather than to the immediate vicinity of one of the boreholes in the pair. The fracture-zone's $S$ value determines the relative magnitude of the flow response (fig. 11B). The previously established $T$ estimates and the type curve that most closely resembles the shape of the transientflow response can be used be used to adjust the $S$ values such that the simulated flow matches the measured flow.

Four cross-hole flow tests were completed at the Watervliet site. The stress for two of the cross-hole flow tests was applied by injection into boreholes believed to be on the periphery of the most contaminated area to minimize the amount of contaminated water to be disposed of and the spread of contaminants. Monitoring wells 34 and 59 were used for injection because they both intersected a single, zone; thus, the exact point at which the head change was applied to the fracture system was known. The injection rate in both tests was $4 \mathrm{gal} / \mathrm{min}$. The other two tests were conducted by extraction from corehole 65. An inflatable packer set at $50 \mathrm{ft}$ was used to isolate the upper and lower fracture groups in corehole 65 during these two tests. In the first of these tests, $1 \mathrm{gal} / \mathrm{min}$ was pumped from below the packer and in the second, $3 \mathrm{gal} / \mathrm{min}$ was pumped from above the packer. The extraction rate was increased from 3 to 6 $\mathrm{gal} / \mathrm{min}$ during the latter part of the second test.

During the cross-hole tests, fluid logs, flowmeter profiles, and transient flowmeter measurements at selected depth(s) were made in the two coreholes that penetrate multiple flow zones and whose water levels were significantly affected by the stress. These were corehole 65 during injection into monitoring wells 34 and 59, and corehole 71 during injection into monitoring wells 34 and 59 and extraction from the lower and upper fracture zones in corehole 65. Flow was measured at a depth of $50 \mathrm{ft}$ in corehole 71 in between the fractures at 28 and $65 \mathrm{ft}$. Corehole 65 was divided into an upper fracture group (fractures at 24 and $35 \mathrm{ft}$ ) and lower group (fractures at 78, 88, and $110 \mathrm{ft}$ ), and flow was measured at a depth of $60 \mathrm{ft}$ in between. The transient-flow responses associated with single, isolated, and short-circuited fracture configurations, as shown in figures 8,9 , and 10 , serve as the basic type curves to which the results of the Watervliet cross-hole tests were fit through adjustment of the $T$ and $S$ values.

\section{Injection into Monitoring Well 34}

Injection at a rate of $4 \mathrm{gal} / \mathrm{min}$ into monitoring well 34 produced the following water-level increase in the monitoring wells and coreholes: $34(5.14 \mathrm{ft}), 59$ $(1.12 \mathrm{ft}), 65(2.51 \mathrm{ft})$, and 71 (1.24 ft) (fig. 12 and table $3)$. More than 80 percent of the measured water-level changes occurred within 15 minutes of the start of injection, and the changes paralleled each other and were less than $0.01 \mathrm{ft} / \mathrm{min}$ within 30 minutes. These water-level changes indicate a strong hydraulic connection between the boreholes. The close similarity of the water-level changes in corehole 71 to those in monitoring well 59, despite the much greater distance of the latter from the injection point, suggests an extremely direct connection between the two. 
A
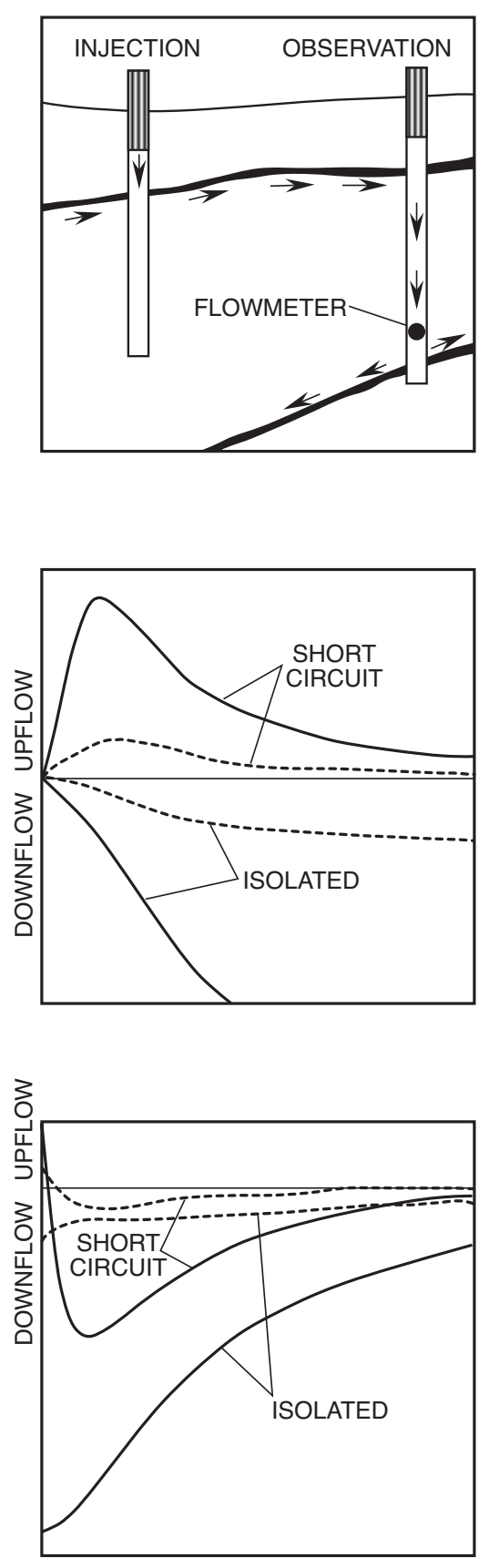

B

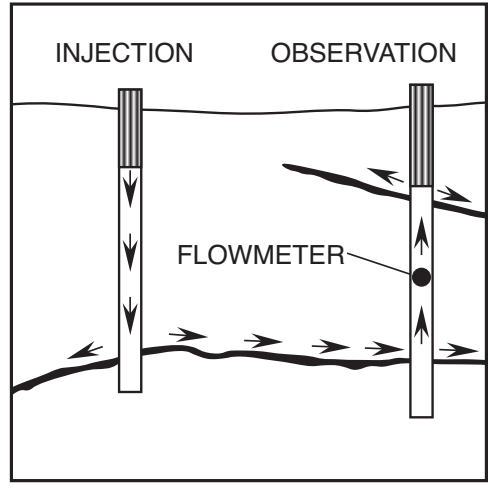

FRACTURE CONFIGURATION
INJECTION RESPONSE
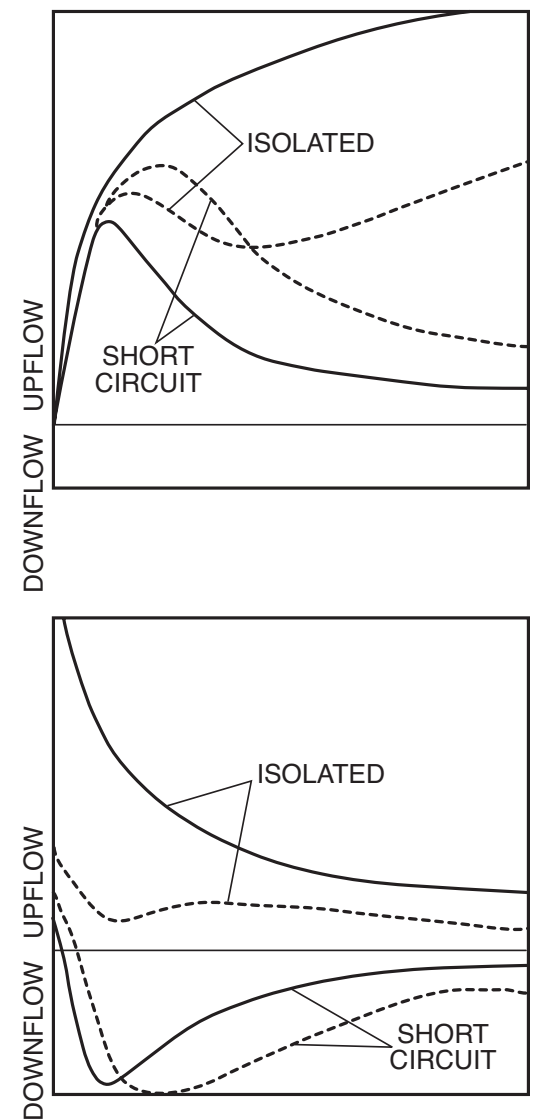

RECOVERY

RESPONSE

\section{EXPLANATION}

Short-circuited and isolated examples with primary and secondary fracture $T$ values of $100 \mathrm{ft}^{2} / \mathrm{d}$ are shown as a solid line. Short-circuited and isolated examples with primary and secondary fracture $T$ values of $100 \mathrm{ft}^{2} / \mathrm{d}$ and $10 \mathrm{ft}^{2} / \mathrm{d}$, respectively, are shown as a dashed line. Fracture $S$ values equal $1 \times 10^{-5}$, borehole separation is $100 \mathrm{ft}$, and the injection rate is $10 \mathrm{gal} / \mathrm{min}$ for all examples.

Figure 10. Cross-hole flow tests of fracture connections between injection and observation boreholes and corresponding transient type-curve response for: A. A shallow fracture connection inducing flow to a deep fracture in the observation borehole. B. A deep fracture connection inducing flow to a shallow fracture in the observation borehole. 
A

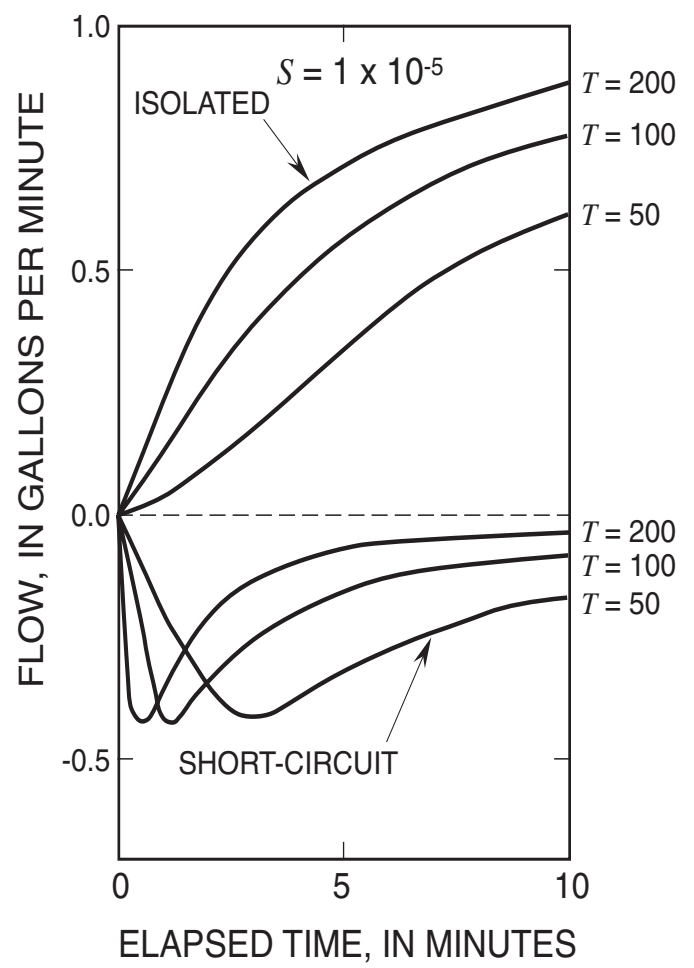

B

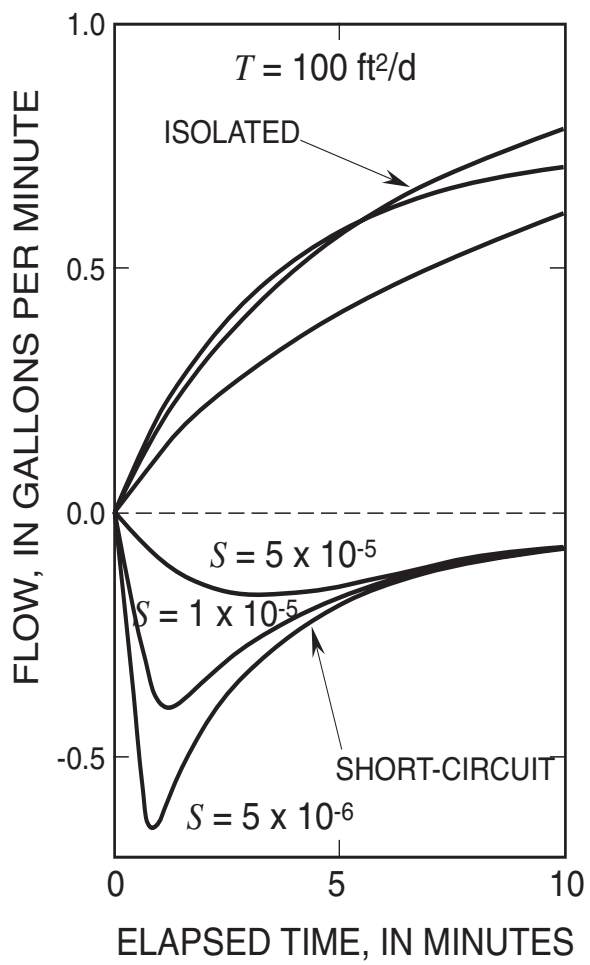

Figure 11. Example of the effects of variations in (A) fracture transmissivity, and (B) fracture storage coefficients on the shape and magnitude of cross-hole flow type curves for the fracture connections depicted in figure $9 \mathrm{~A}$.

Water-level changes in monitoring well 51 and corehole 68 were less than $0.05 \mathrm{ft}$.

Injection into monitoring well 34 more than tripled the rate of upflow from the $65-\mathrm{ft}$ fracture zone to the 28 -ft zone in corehole 71 in relation to ambient conditions. Model analysis of the cross-flow data indicates that the single fracture-flow zone at monitoring well 34 is directly connected to the $65-\mathrm{ft}$ zone in corehole 71 (fig. 13A). A $T$ value of $150 \mathrm{ft}^{2} / \mathrm{d}$ and $S$ value of $1 \times 10^{-5}$ for the hydraulic connection between the boreholes provides a good fit between the measured and simulated flow. This $T$ estimate is somewhat smaller than those obtained in the single borehole tests and may indicate a constriction in the fracture connection between the boreholes. The single-fracture and short-circuited fracture configurations produce nearly identical type curves because the lower fractures at corehole 71 are much more transmissive than the upper fractures and therefore, dominate the response.

Injection into monitoring well 34 caused flow in corehole 65 to reverse from upward to downward between the upper fracture group (24 and $35 \mathrm{ft}$ ) and the lower fracture group (78 ft and deeper) (fig. 14). The 20-second maximum firing frequency of the heat-pulse flowmeter, together with equipment malfunctions, prevented effective capture of the early response of the direct connection between the fracture in borehole 34 and the upper fracture group at corehole 65 (fig. 13B). A fracture connection with a $T$ value of $100 \mathrm{ft}^{2} / \mathrm{d}$ and $S$ value of $5 \times 10^{-6}$ is consistent with the available data and single-hole test in corehole 65 (fig. 4 and table 2). The flow data agree with a model in which the upper and lower fracture groups in corehole 65 are isolated from each other during the first three minutes after the start of injection. The failure of the measured flow to continue to increase after 3 minutes indicates that the head change caused by the injection had propagated to the lower fracture group. This suggests a connection between the upper and lower fractures groups in the area near corehole 65 .

The measured recovery was faster than the model predictions, which indicates that the head in the lower group increases more slowly during injection 
A
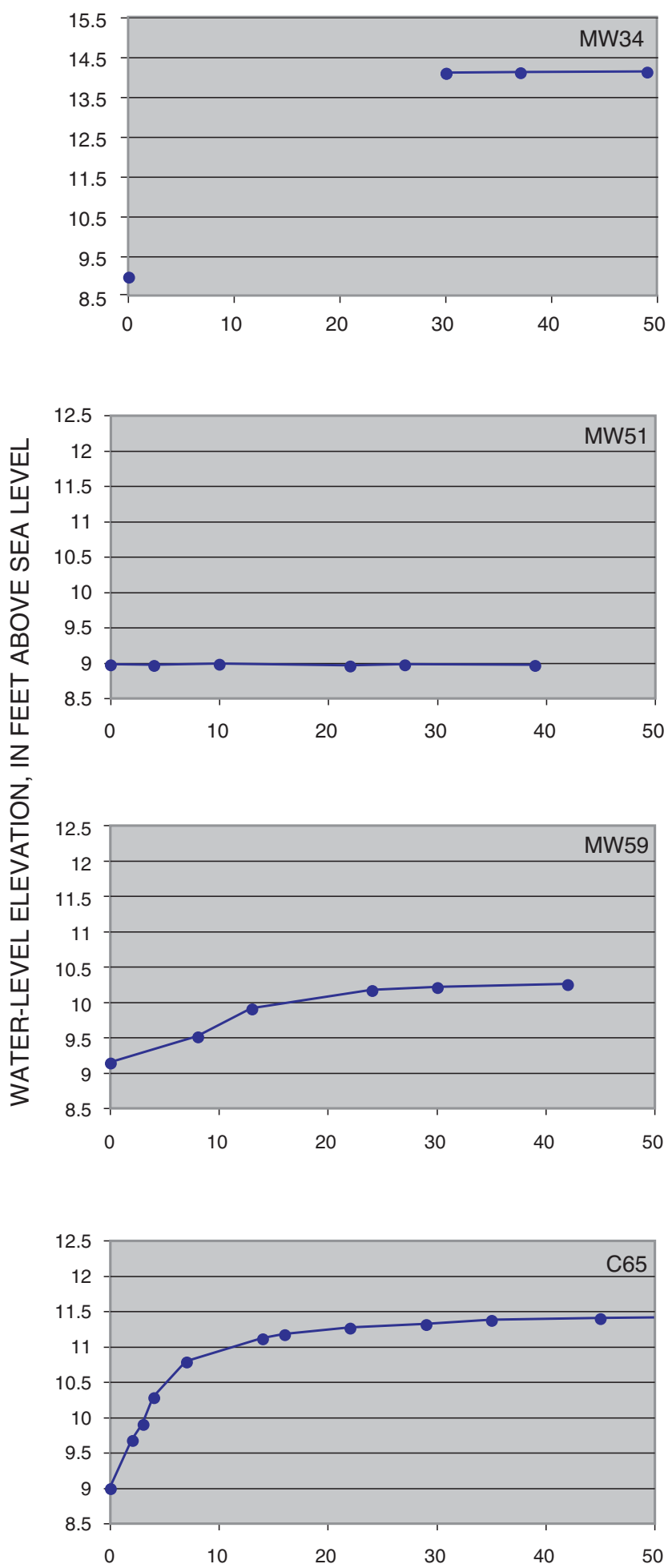

B
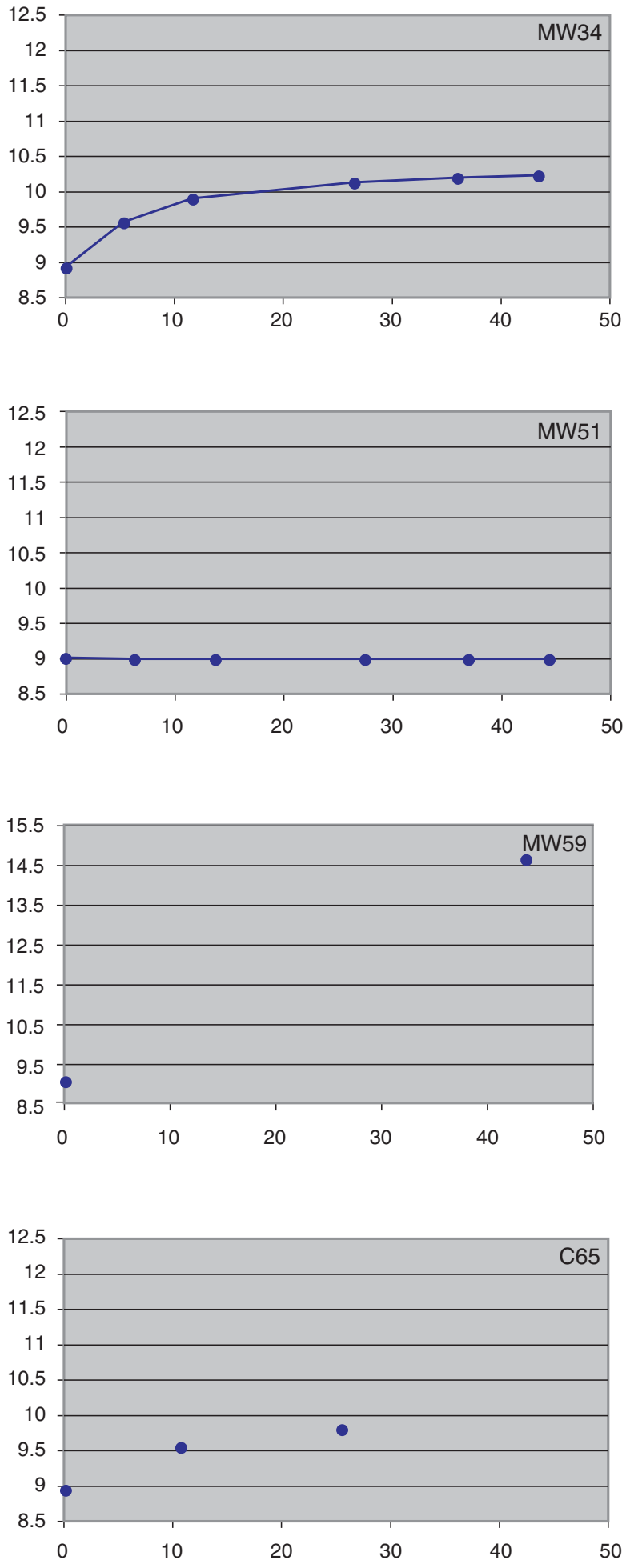

ELAPSED TIME, IN MINUTES

Figure 12. Water levels in the monitoring wells and coreholes for the cross-hole injection tests: A. Injection into monitoring well 34. B. Injection into monitoring well 59. (Locations are shown in fig. 2.) 

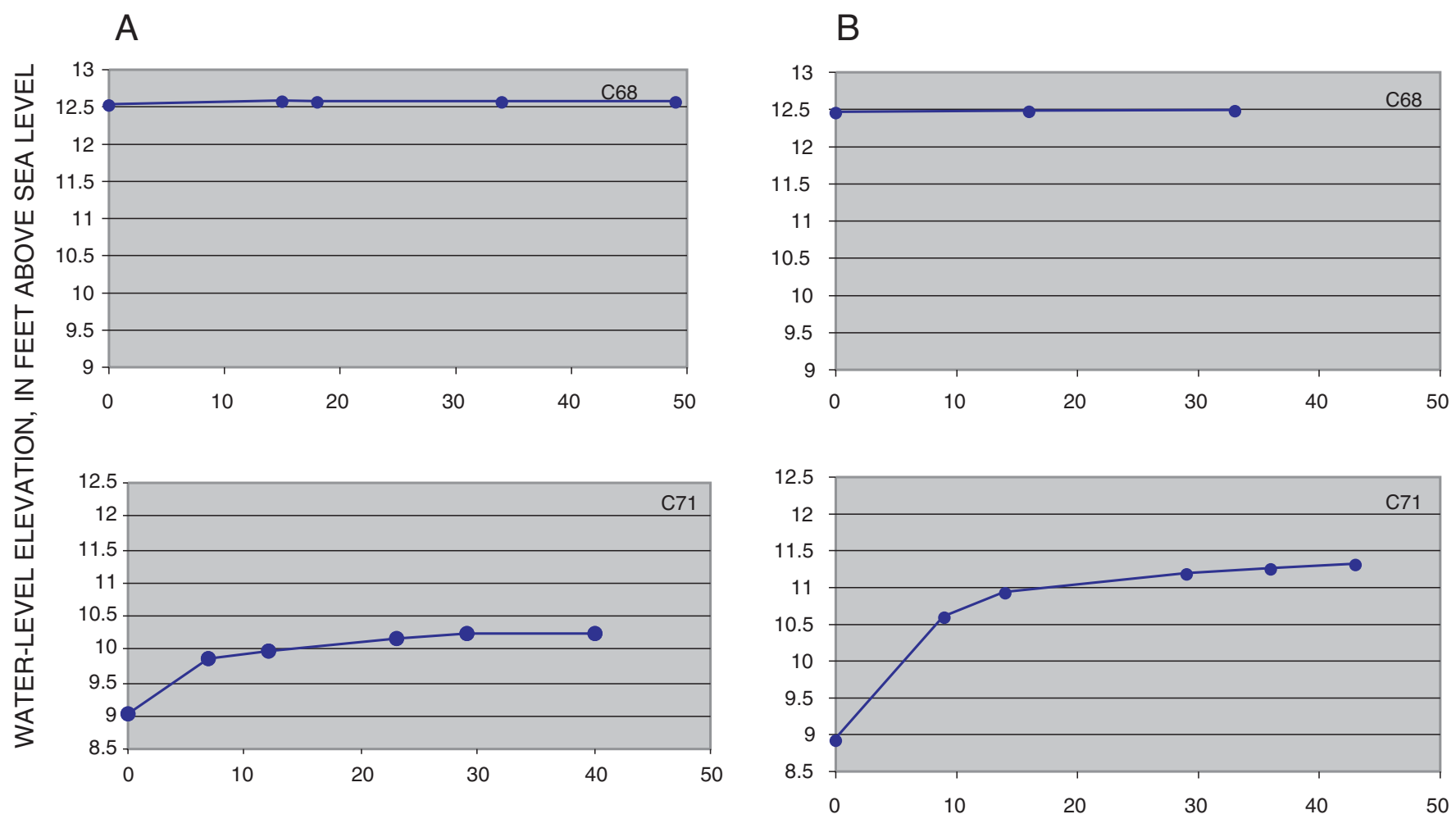

ELAPSED TIME, IN MINUTES

Figure 12. (continued) Water levels in the monitoring wells and coreholes for the cross-hole injection tests: A. Injection into monitoring well 34. B. Injection into monitoring well 59. (Locations are shown in fig. 2.)

than that in the upper group, then decreases more slowly during recovery. This results in a slower relaxation of the head in the lower group than in the upper zone during recovery. The result is a distinct "overshoot" during the early phase of recovery. Thus, the cross-hole test supports the $T$ estimates for the fractures at corehole 65 and indicates a hydraulic connection between the upper and lower fracture groups. The connection is less direct than that between the shallow fractures at monitoring well 34 and corehole 65 because the measured flows lie closer to the isolated fracture prediction than to the strong upflow simulated for the short-circuited configuration depicted in figure 10A.

\section{Injection into Monitoring Well 59}

Injection at a rate of $4 \mathrm{gal} / \mathrm{min}$ into monitoring well 59 produced the following water-level changes in the monitoring wells and coreholes: $34(1.28 \mathrm{ft}), 59$ $(\sim 5 \mathrm{ft}), 65(0.85 \mathrm{ft})$, and $71(2.39 \mathrm{ft})(\mathrm{fig} .12$ and table
3). This response was similar to the response of the injection at monitoring well 34 . The water-level changes in monitoring well 51 and corehole 68 were less than $0.05 \mathrm{ft}$.

Injection into monitoring well 59 increased the rate of upflow from the $65-\mathrm{ft}$ fracture zone to the $28-\mathrm{ft}$ zone in corehole 71 by almost an order of magnitude in relation to ambient conditions. The hydraulic connection between monitoring well 59 and corehole 71 is so direct that the transient flow was difficult to capture with the 20-second maximum firing frequency of the heat-pulse flowmeter (fig. 13C). Model-type curves representing isolated fractures and shortcircuited fractures for the zones at 65 and $28 \mathrm{ft}$ at corehole 71, based on the $T$ value obtained from the single-hole tests and an assumed $S$ value of $5 \times 10^{-5}$, are presented. The single-fracture type curve is omitted because it is virtually the same curve as the short-circuited configuration. The measured transient flow appears to lie about midway between the 
Table 3. Water levels recorded in monitoring wells and coreholes during cross-hole flow tests at the Watervliet Arsenal, Albany County, N.Y., $2000-01$. [Time is in minutes. Water levels are in feet above sea level. Gal/min, gallons per minute. Dashes indicate no measurement. Locations are shown in fig. 2.]

\begin{tabular}{|c|c|c|c|c|c|c|c|c|c|c|c|c|c|}
\hline \multicolumn{2}{|c|}{ Corehole 65} & \multicolumn{2}{|c|}{ Corehole 71} & \multicolumn{2}{|c|}{ Monitoring well 59} & \multicolumn{2}{|c|}{ Monitoring well 34} & \multicolumn{2}{|c|}{ Corehole 68} & \multicolumn{2}{|c|}{ Monitoring well 51} & \multicolumn{2}{|c|}{ Monitoring well 58} \\
\hline $\begin{array}{l}\text { Elapsed } \\
\text { time }\end{array}$ & $\begin{array}{l}\text { Water } \\
\text { level }\end{array}$ & $\begin{array}{l}\text { Elapsed } \\
\text { time }\end{array}$ & $\begin{array}{l}\text { Water } \\
\text { level }\end{array}$ & $\begin{array}{c}\text { Elapsed } \\
\text { time }\end{array}$ & $\begin{array}{l}\text { Water } \\
\text { level }\end{array}$ & $\begin{array}{c}\text { Elapsed } \\
\text { time }\end{array}$ & $\begin{array}{l}\text { Water } \\
\text { level }\end{array}$ & $\begin{array}{c}\text { Elapsed } \\
\text { time }\end{array}$ & $\begin{array}{l}\text { Water } \\
\text { level }\end{array}$ & $\begin{array}{c}\text { Elapsed } \\
\text { time }\end{array}$ & $\begin{array}{l}\text { Water } \\
\text { level }\end{array}$ & $\begin{array}{c}\text { Elapsed } \\
\text { time }\end{array}$ & $\begin{array}{l}\text { Water } \\
\text { level }\end{array}$ \\
\hline \multicolumn{14}{|c|}{ Injection of $4 \mathrm{gal} / \mathrm{min}$ into monitoring well 34} \\
\hline 0 & 8.99 & 0 & 9.01 & 0 & 9.16 & 0 & 8.98 & 0 & 12.52 & 0 & 8.97 & - & - \\
\hline 2 & 9.67 & 7 & 9.84 & 8 & 9.53 & 30 & 14.09 & 15 & 12.57 & 4 & 8.96 & - & - \\
\hline 3 & 9.90 & 12 & 9.96 & 13 & 9.93 & 37 & 14.11 & 18 & 12.56 & 10 & 8.98 & - & - \\
\hline 7 & 10.78 & 29 & 10.22 & 30 & 10.23 & - & - & 49 & 12.56 & 27 & 8.97 & - & - \\
\hline 14 & 11.11 & 40 & 10.25 & 42 & 10.28 & - & - & - & - & 39 & 8.96 & - & - \\
\hline 16 & 11.17 & - & - & - & - & - & - & - & - & - & - & - & - \\
\hline 22 & 11.26 & - & - & - & - & - & - & - & - & - & - & - & - \\
\hline 29 & 11.31 & - & - & - & - & - & - & - & - & - & - & - & - \\
\hline 35 & 11.37 & - & - & - & - & - & - & - & - & - & - & - & - \\
\hline 45 & 11.40 & - & - & - & - & - & - & - & - & - & - & - & - \\
\hline \multicolumn{14}{|c|}{ Injection of $4 \mathrm{gal} / \mathrm{min}$ into monitoring well 59} \\
\hline 0 & 8.92 & 0 & 8.92 & 0 & 9.12 & 0 & 8.90 & 0 & 12.45 & 0 & 9.00 & - & - \\
\hline 10 & 9.52 & 9 & 10.59 & 40 & 14.65 & 5 & 9.53 & 16 & 12.47 & 6 & 8.99 & - & - \\
\hline 24 & 9.77 & 14 & 10.92 & - & - & 11 & 9.86 & 33 & 12.48 & 13 & 8.99 & - & - \\
\hline- & - & 29 & 11.18 & - & - & 25 & 10.08 & - & - & 26 & 8.99 & - & - \\
\hline- & - & 36 & 11.25 & - & - & 34 & 10.15 & - & - & 35 & 8.99 & - & - \\
\hline- & - & 43 & 11.31 & - & - & 41 & 10.18 & - & - & 42 & 8.99 & - & - \\
\hline \multicolumn{14}{|c|}{ Extraction of $1 \mathrm{gal} / \mathrm{min}$ from lower zone of monitoring well 65} \\
\hline 0 & 8.96 & 0 & 8.96 & 0 & 9.13 & 0 & 8.90 & 0 & 12.33 & 0 & 9.29 & 0 & 9.56 \\
\hline 14 & 7.96 & 12 & 8.69 & 1 & 8.95 & 5 & 8.48 & 4 & 12.32 & 4 & 9.29 & 3 & 9.54 \\
\hline 18 & 7.95 & 18 & 8.68 & 11 & 8.89 & 17 & 8.43 & 15 & 12.32 & 18 & 9.29 & 13 & 9.54 \\
\hline 48 & 7.96 & 28 & 8.67 & 19 & 8.86 & 31 & 8.43 & 23 & 12.31 & 32 & 9.29 & 22 & 9.50 \\
\hline- & - & 43 & 8.65 & 34 & 8.85 & 64 & 8.41 & 60 & 12.31 & 64 & 9.29 & 61 & 9.39 \\
\hline- & - & 172 & 8.59 & 103 & 8.82 & 149 & 8.39 & 146 & 12.30 & 150 & 9.29 & 147 & 9.16 \\
\hline- & - & - & - & 149 & 8.79 & - & - & - & - & - & - & - & - \\
\hline
\end{tabular}




\begin{tabular}{|c|c|c|c|c|c|c|c|c|c|c|c|c|c|}
\hline \multicolumn{2}{|c|}{ Corehole 65} & \multicolumn{2}{|c|}{ Corehole 71} & \multicolumn{2}{|c|}{ Monitoring well 59} & \multicolumn{2}{|c|}{ Monitoring well 34} & \multicolumn{2}{|c|}{ Corehole 68} & \multicolumn{2}{|c|}{ Monitoring well 51} & \multicolumn{2}{|c|}{ Monitoring well 58} \\
\hline $\begin{array}{l}\text { Elapsed } \\
\text { time }\end{array}$ & $\begin{array}{l}\text { Water } \\
\text { level }\end{array}$ & $\begin{array}{c}\text { Elapsed } \\
\text { time }\end{array}$ & $\begin{array}{l}\text { Water } \\
\text { level }\end{array}$ & $\begin{array}{c}\text { Elapsed } \\
\text { time }\end{array}$ & $\begin{array}{l}\text { Water } \\
\text { level }\end{array}$ & $\begin{array}{l}\text { Elapsed } \\
\text { time }\end{array}$ & $\begin{array}{l}\text { Water } \\
\text { level }\end{array}$ & $\begin{array}{l}\text { Elapsed } \\
\text { time }\end{array}$ & $\begin{array}{l}\text { Water } \\
\text { level }\end{array}$ & $\begin{array}{c}\text { Elapsed } \\
\text { time }\end{array}$ & $\begin{array}{l}\text { Water } \\
\text { level }\end{array}$ & $\begin{array}{l}\text { Elapsed } \\
\text { time }\end{array}$ & $\begin{array}{l}\text { Water } \\
\text { level }\end{array}$ \\
\hline \multicolumn{14}{|c|}{ Extraction of $3 \mathrm{gal} / \mathrm{min}$ from upper zone of monitoring well 65 (increase to $6 \mathrm{gal} / \mathrm{min}$ at $155 \mathrm{~min}$ ) } \\
\hline 0 & 9.00 & 0 & 8.94 & 0 & 9.17 & 0 & 8.94 & 0 & 12.36 & 0 & 9.29 & 0 & 9.53 \\
\hline 3 & 3.82 & 5 & 8.51 & 15 & 8.47 & 5 & 8.00 & 11 & 12.35 & 13 & 9.29 & 7 & 9.55 \\
\hline 8 & 1.83 & 8 & 8.34 & 31 & 8.33 & 9 & 7.97 & 26 & 12.34 & 28 & 9.27 & 10 & 9.55 \\
\hline 17 & 0.67 & 10 & 8.31 & 46 & 8.69 & 17 & 7.47 & 37 & 12.34 & 41 & 9.28 & 19 & 9.55 \\
\hline 22 & 1.28 & 11 & 8.30 & 57 & 8.31 & 23 & 7.03 & 53 & 12.34 & 54 & 9.28 & 24 & 9.53 \\
\hline 39 & 2.62 & 15 & 8.10 & 105 & 8.31 & 40 & 6.99 & 65 & 12.33 & 104 & 9.28 & 38 & 9.48 \\
\hline 47 & 2.55 & 22 & 8.03 & 118 & 8.25 & 48 & 7.17 & 112 & 12.29 & 162 & 9.28 & 52 & 9.42 \\
\hline 61 & 2.58 & 29 & 8.03 & 165 & 7.92 & 62 & 7.18 & 146 & 12.29 & 171 & 9.28 & 64 & 9.39 \\
\hline 88 & 2.51 & 37 & 8.05 & 172 & 7.73 & 103 & 7.16 & 167 & 12.28 & - & - & 110 & 9.24 \\
\hline 106 & 2.51 & 44 & 8.03 & 188 & 7.59 & 115 & 7.11 & 175 & 12.27 & - & - & 166 & 9.04 \\
\hline 113 & 2.51 & 70 & 7.99 & 201 & 7.54 & 166 & 6.19 & 190 & 12.25 & - & - & 174 & 8.97 \\
\hline 160 & -9.96 & 91 & 7.97 & - & - & 171 & 5.84 & 207 & 12.23 & - & - & 189 & 8.87 \\
\hline 170 & -18.54 & 136 & 7.96 & - & - & 186 & 5.65 & - & - & - & - & 198 & 8.79 \\
\hline 185 & -18.84 & 156.5 & 7.83 & - & - & 200 & 5.62 & - & - & - & - & 208 & 8.71 \\
\hline- & - & 158.5 & 7.71 & - & - & - & - & - & - & - & - & - & - \\
\hline- & - & 159.5 & 7.63 & - & - & - & - & - & - & - & - & - & - \\
\hline- & - & 164.5 & 7.50 & - & - & - & - & - & - & - & - & - & - \\
\hline- & - & 169.5 & 7.41 & - & - & - & - & - & - & - & - & - & - \\
\hline- & - & 174.5 & 7.38 & - & - & - & - & - & - & - & - & - & - \\
\hline- & - & 178.5 & 7.33 & - & - & - & - & - & - & - & - & - & - \\
\hline- & - & 187.5 & 7.35 & - & - & - & - & - & - & - & - & - & - \\
\hline- & - & 192.5 & 7.23 & - & - & - & - & - & - & - & - & - & - \\
\hline- & - & 197.5 & 7.22 & - & - & - & - & - & - & - & - & - & - \\
\hline- & - & 202.5 & 7.20 & - & - & - & - & - & - & - & - & - & - \\
\hline
\end{tabular}



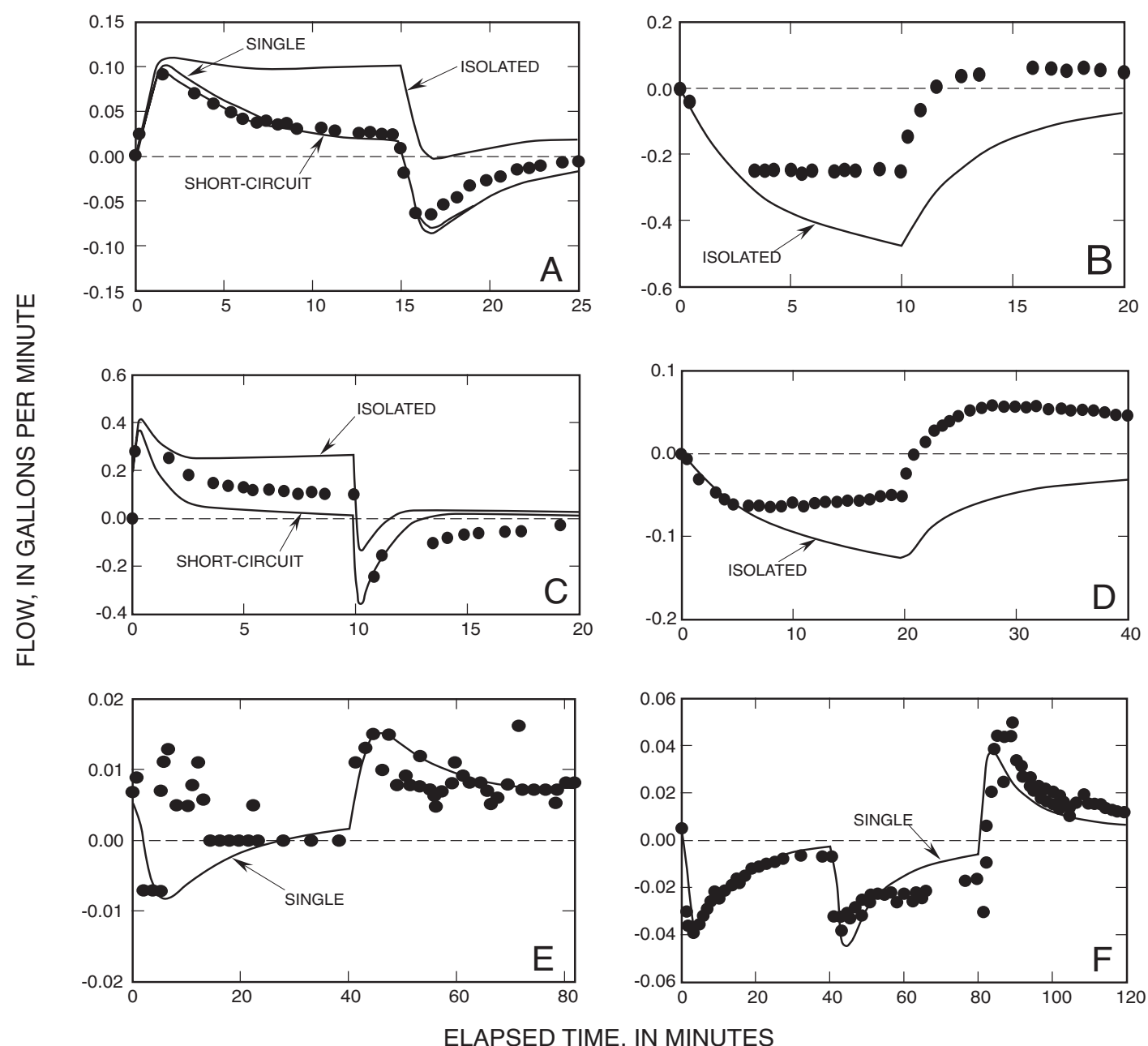

Figure 13. Measured flow (dots) and model type curves (solid lines) for the observation boreholes during the cross-hole tests: A. Corehole 71 with flowmeter at $50 \mathrm{ft}$ during injection into monitoring well 34.

B. Corehole 65 with flowmeter at $60 \mathrm{ft}$ during injection into monitoring well 34. C. Corehole 71 with flowmeter at $50 \mathrm{ft}$ during the injection into monitoring well 59. D. Corehole 65 with flowmeter at $60 \mathrm{ft}$ during injection into monitoring well 59. E. Corehole 71 with flowmeter at $50 \mathrm{ft}$ during extraction from the lower part of corehole 65. F. Corehole 71 with flowmeter at $50 \mathrm{ft}$ during extraction from the upper

completely isolated flow and short-circuited or singlefracture flow.

Injection into monitoring well 59 caused flow in corehole 65 to reverse from upward to downward (fig. 14). The downflow rate was less than one-half that obtained for the monitoring well 34 injection. A $T$ value of $250 \mathrm{ft}^{2} / \mathrm{d}$ and $S$ value of $1 \times 10^{-5}$ for an isolated connection between the upper fracture group (24 and $35 \mathrm{ft}$ ) at corehole 65 and the $92-\mathrm{ft}$ fracture zone at monitoring well 59 provide a good fit between measured and simulated flow at early times (fig. 13D). The measured flow's obvious lag behind the model simulation after about 5 minutes indicates a connection between the upper and lower groups of fractures near corehole 65 . The expected overshoot during the recovery also is evident. Even so, the measured flow lies closer to the isolated configuration because the short-circuited configuration would predict strong upflow, as in figure 10A.

\section{Extraction from Lower Part of Corehole 65}

Extraction at a rate of $1 \mathrm{gal} / \mathrm{min}$ from the lower part of corehole 65 produced the following drawdown in the monitoring wells and coreholes: $34(0.51 \mathrm{ft}), 58$ (0.40), $59(0.34 \mathrm{ft})$, upper part of $65(1.00 \mathrm{ft})$, and 71 $(0.37 \mathrm{ft})$ (fig. 15 and table 3$)$. The water level in monitoring well 58 showed a delayed linear response, in contrast to the almost instantaneous logarithmic 


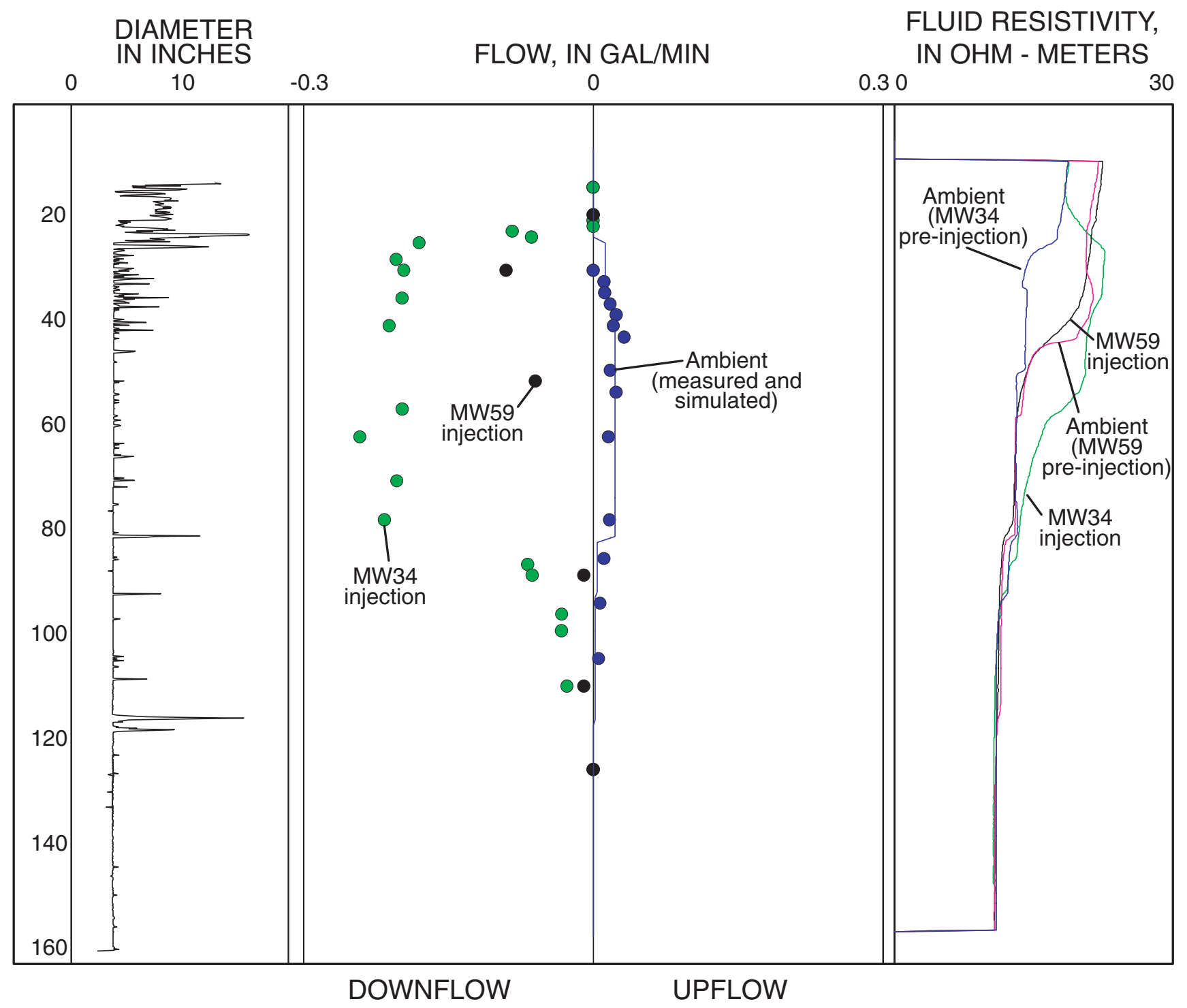

Figure 14. Wellbore diameter, flow, and fluid resistivity for corehole 65 during injection cross-hole tests at monitoring well 34 and 59. (Locations are shown in fig. 2.) 
A
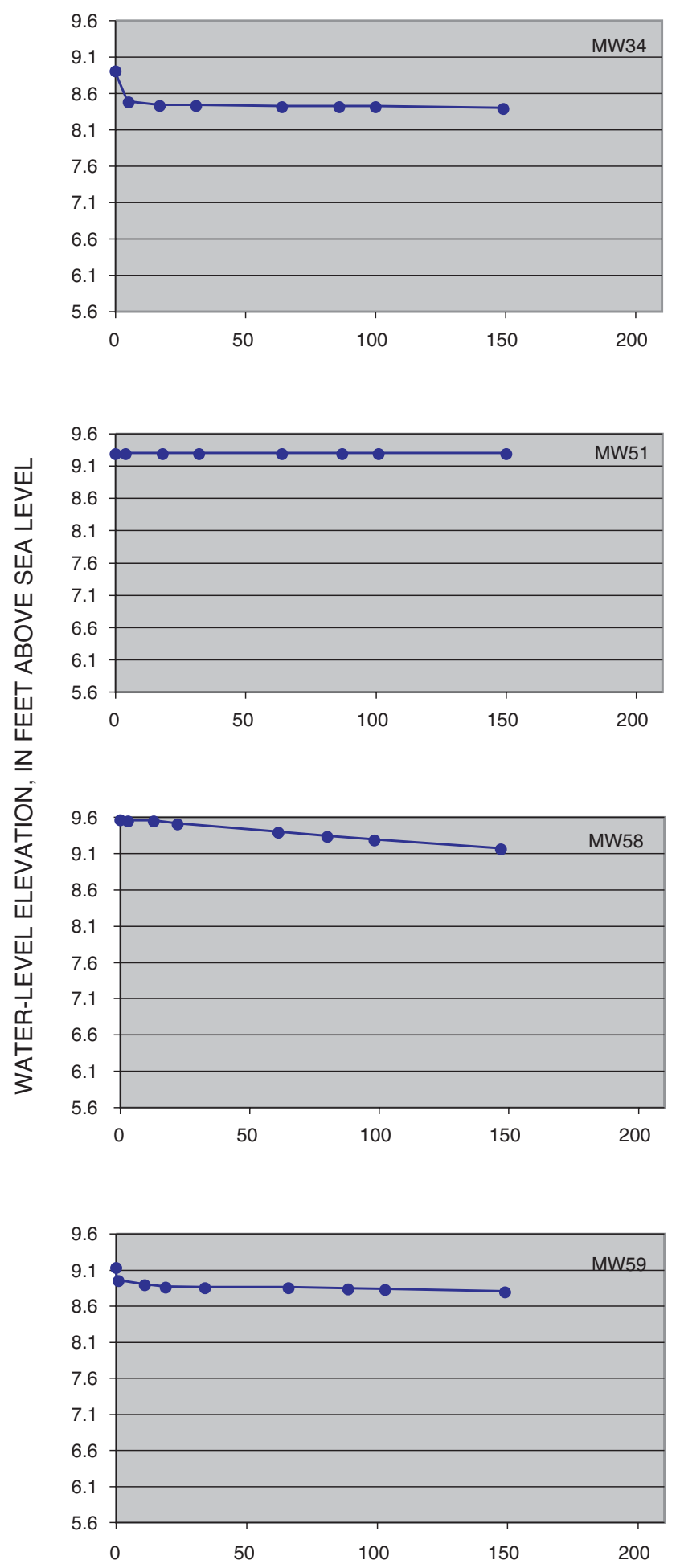

B
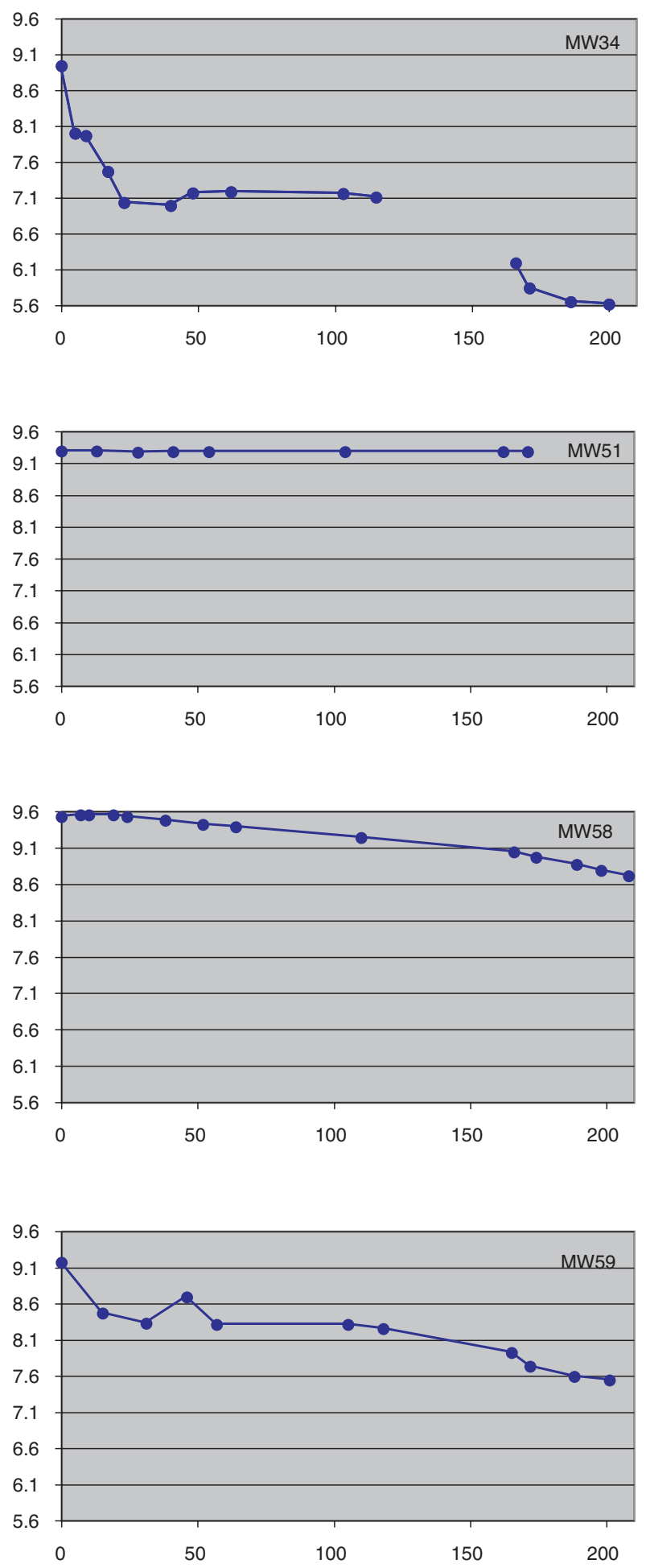

ELAPSED TIME, IN MINUTES

Figure 15. Water levels in the monitoring wells and coreholes for the cross-hole extraction tests: A. Extraction from lower part of corehole 65. B. Extraction from upper part of corehole 65. (Locations are shown in fig. 2.) 
A
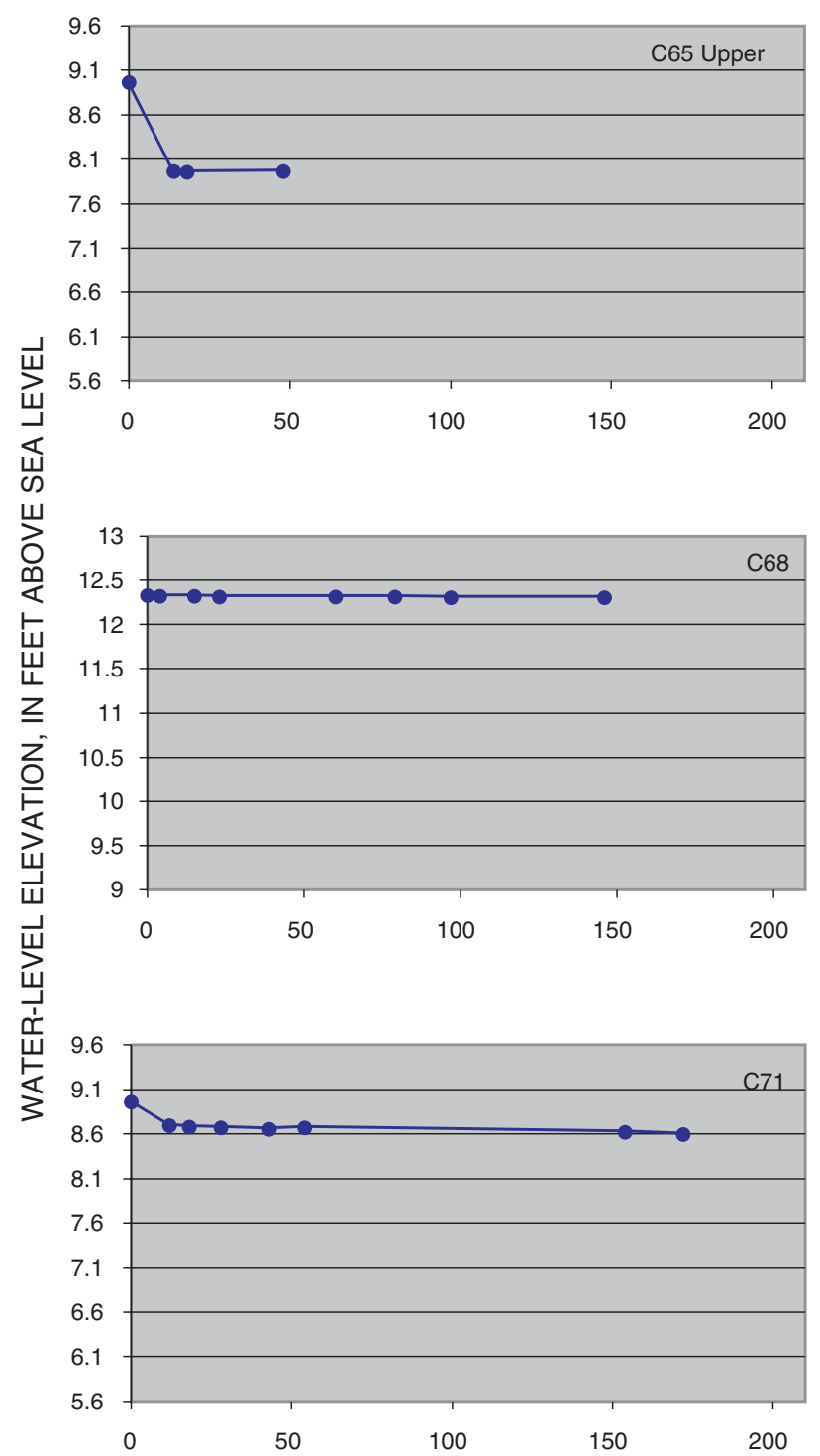

B
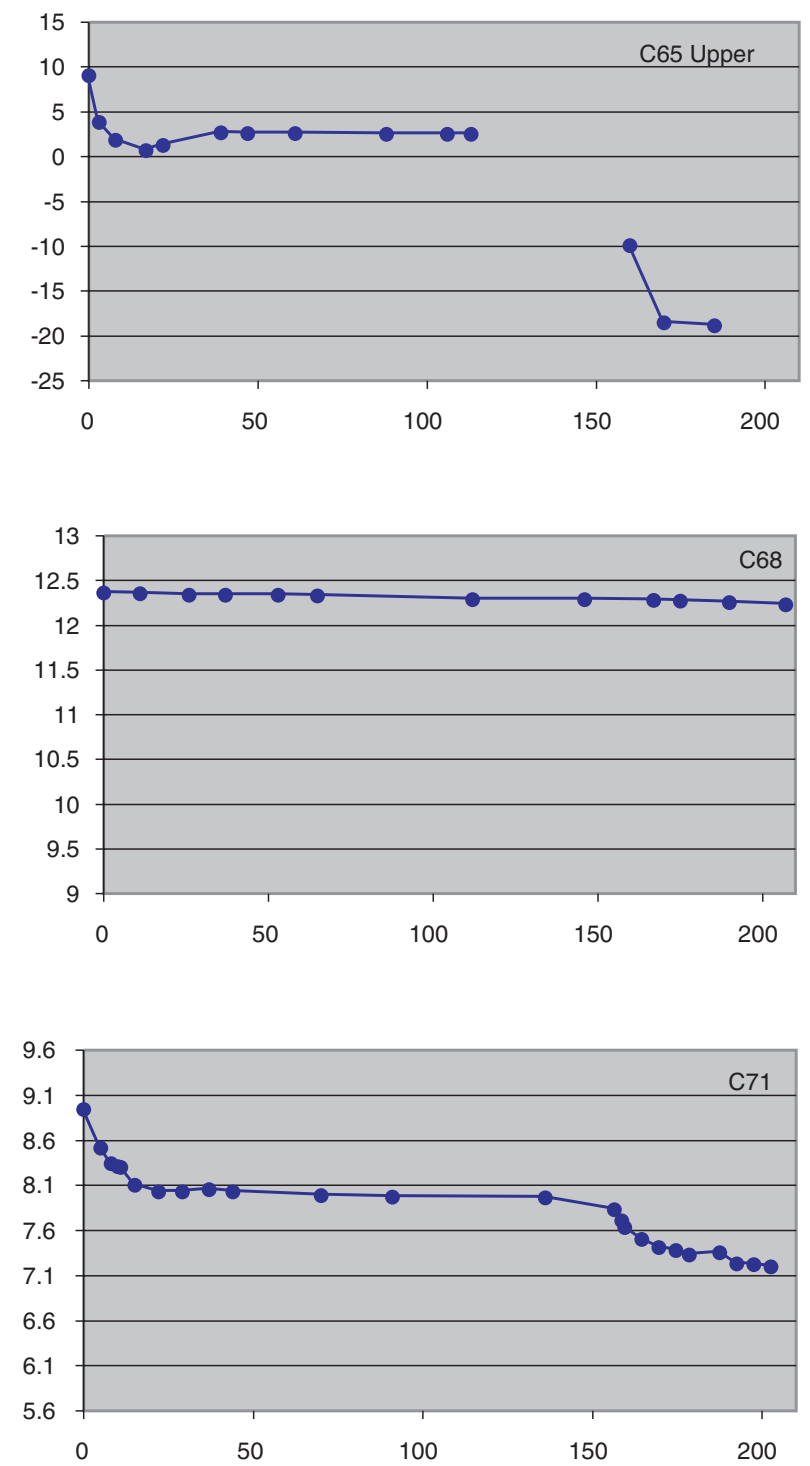

ELAPSED TIME, IN MINUTES

Figure 15. (continued) Water levels in the monitoring wells and coreholes for the cross-hole extraction tests:

A. Extraction from lower part of corehole 65. B. Extraction from upper part of corehole 65. (Locations are shown in fig. 2.)

response in the other boreholes. This response is not surprising, given the low transmissivity of the flow zone in well 58 (fig. 4 and table 2). Water-level changes in monitoring well 51 and corehole 68 were less than $0.05 \mathrm{ft}$. The continuous water-level recorder in corehole 72 did not function properly during the extraction tests, and data were lost, but data recorded after the tests indicate that the water level in the corehole is affected by tides (fig. 16). Water-level changes based on the few manual measurements made during the tests are consistent with this tidal effect and did not appear to be affected by extraction from corehole 65.

The extraction induced a weak but measurable response in corehole 71 (fig. 13E). This response matches the type curve for a direct connection between the lower fracture group at corehole 65 and the fracture zone at 65 feet at corehole 71 if the irregular distribution of upflow after the initial downflow response to extraction is disregarded. The 


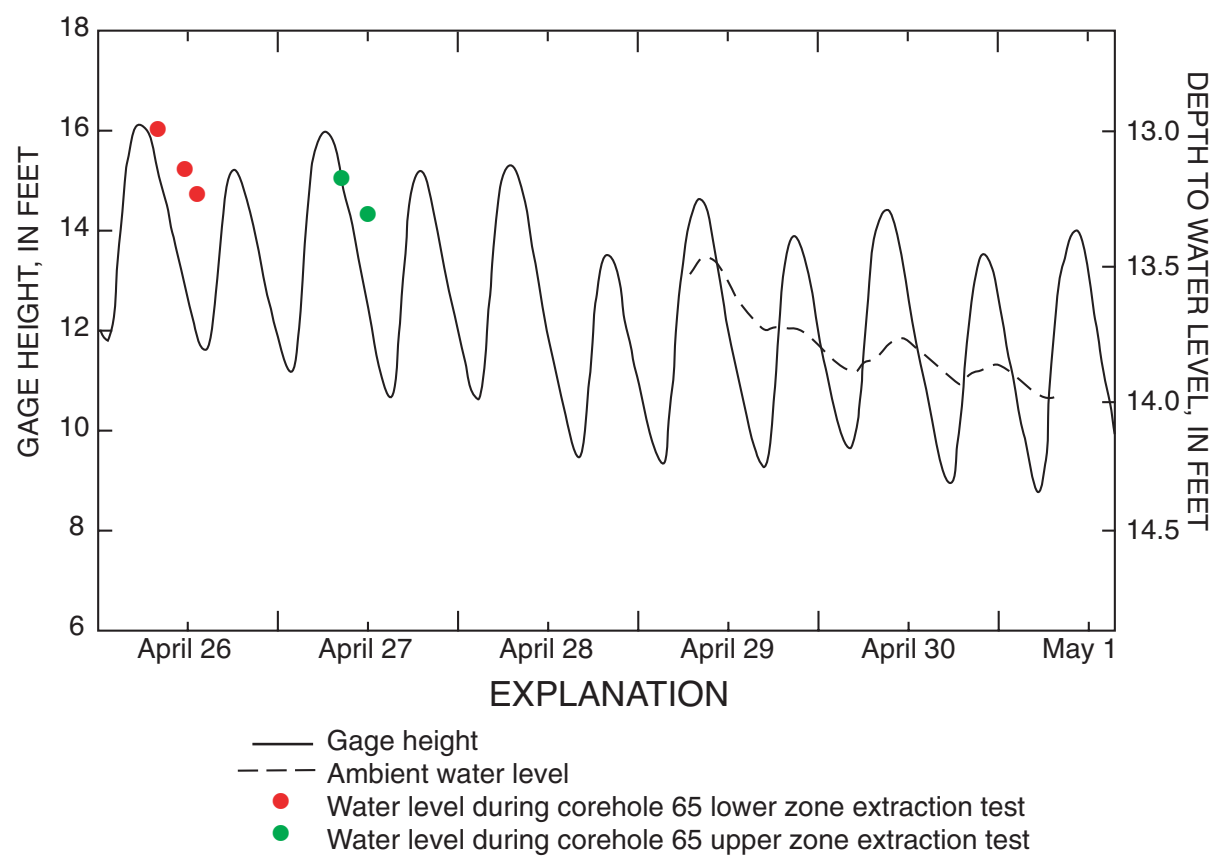

Figure 16. Depth to water level in corehole 72 and gage height in the adjacent Hudson River at Albany, April 26 to May 1, 2001. (Location is shown in fig. 2.)

response to extraction is poorly defined because the induced downflow is superimposed on a weak ambient upflow, which barely exceeds the $0.005 \mathrm{gal} / \mathrm{min}$ detection limit for the heat-pulse flowmeter. Thus, the induced downflow is forced to pass through flow values below the detection limit for the flowmeter until the downflow develops beyond the $0.005 \mathrm{gal} / \mathrm{min}$ detection limit. The irregular distribution of upflow data in the 5- to 15-minute period may be attributed to the buoyant rise of the heat pulse in a no-flow situation because the response to extraction exactly cancels the weak ambient flow. The response to recovery in the second half of this test is better defined, probably because the expected upflow response is added to the ambient upflow, and the measured flows are always above the detection limit.

A $T$ value of $80 \mathrm{ft}^{2} / \mathrm{d}$ and $S$ value of $1 \times 10^{-4}$ for a single-fracture connection between the lower part of corehole 65 and the fracture zone at 65 feet at corehole 71 provide a reasonable fit of the measured and simulated flow (fig. 13E). This $T$ value falls between the values for the lower part of corehole $65\left(43 \mathrm{ft}^{2} / \mathrm{d}\right)$ and the fracture zone at corehole $71\left(230 \mathrm{ft}^{2} / \mathrm{d}\right)$ obtained from the single-hole tests (fig. 4 and table 2) and can plausibly represent an average $T$ value for the connection between the lower part of corehole 65 and deep fractures at corehole 71 . The peak response occurs about 5 minutes after the start of extraction or recovery and coincides with the approximately 5 minute time interval after which the measured flow during the injection tests (figs. 13B and D) departs from the simulated response for the fracture groups at corehole 65. The facts that extraction from the lower part of corehole 65 induced a measurable response in corehole 71, and that the measured flow matches the expected response for a direct but weaker fracture connection, confirm the interpretation of the previous cross-hole tests that such a connection exists.

\section{Extraction from Upper Part of Corehole 65}

Extraction at a rate of $3 \mathrm{gal} / \mathrm{min}$ from the upper part of corehole 65 produced the following drawdown in the monitoring wells and coreholes: $34(1.83 \mathrm{ft}), 58$ (0.29), 59 (0.92 ft), upper part of 65 (6.49 ft), and 71 $(0.98 \mathrm{ft})$ (fig. 15 and table 3$)$. No measurable drawdown was detected in monitoring well 58 until after 30 minutes of extraction. Increasing the extraction rate to $6 \mathrm{gal} / \mathrm{min}$ resulted in the following additional drawdown: $34(1.49 \mathrm{ft}), 58(0.53), 59$ (0.71 $\mathrm{ft})$, upper part of $65(21.35 \mathrm{ft})$, and $71(0.76 \mathrm{ft})$. The water level in corehole 68 dropped a total of $0.13 \mathrm{ft}$ in a consistent manner during the test indicating it was possibly affected by the extraction. The water-level 


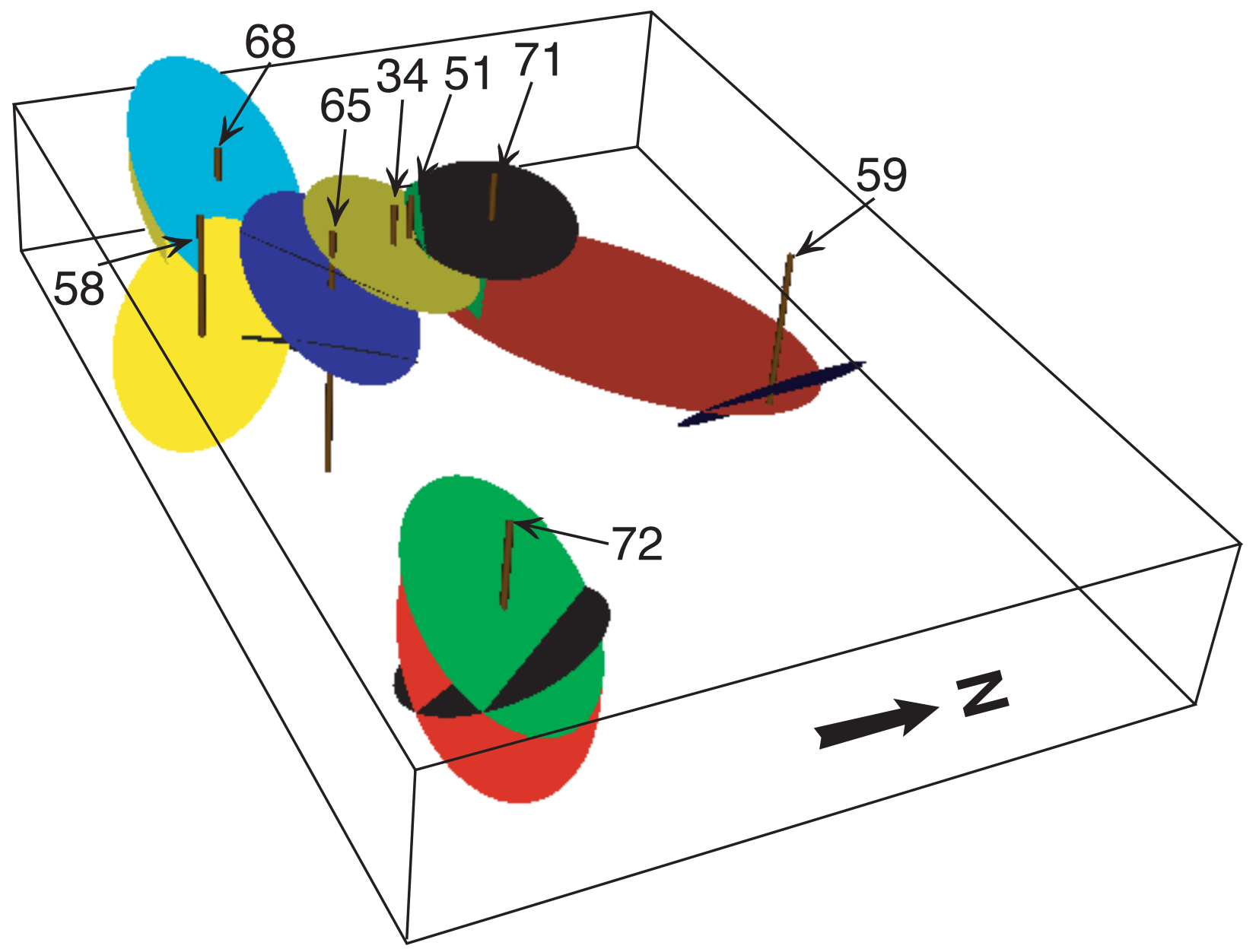

Figure 17. Three-dimensional representation of fracture-flow zones intersected by the monitoring wells and coreholes revised based on hydraulic connections. (Locations are shown in fig. 2.)

change in monitoring well 51 was less than $0.05 \mathrm{ft}$. The water-level change in corehole 72 seems to be consistent with tidal effects (fig. 16).

The measured flow in corehole 71 in response to extraction from the upper part of corehole 65 generally matches the simulated flow for a direct fracture connection with a $T$ value of $100 \mathrm{ft}^{2} / \mathrm{d}$ and $S$ value of $1 \times 10^{-5}$, superimposed on the $0.005 \mathrm{gal} / \mathrm{min}$ ambient upflow (fig. 13F). No previous cross-hole tests were conducted between coreholes 65 and 71, but a direct fracture connection between the upper zone in corehole 65 and the lower zone in corehole 71 had been indicated by the other test analysis. These results support the presence of this connection and its relatively high transmissivity.

The simple radial projection of fracture-flow zones depicted in figure 7 provides a representation that is consistent with the hydraulic connections inferred from the cross-hole testing with one major exception the strong hydraulic connection between fractures in monitoring well 59 and corehole 71. A revised representation is presented in figure 17 that shows a projection of the subhorizontal fracture at 65 $\mathrm{ft}$ in corehole 71 to near corehole 59. The subhorizontal fracture in corehole 71 is a likely candidate for increased projection because of its high transmissivity and large apparent aperture, as seen in figure 6 . The revised representation is by no means definitive or unique, but is consistent with all borehole-wall image and single- and cross-hole flow data collected at the Watervliet site.

\section{SUMMARY}

The results of the geophysical logging and cross-hole testing indicate the presence of an 
interconnected fracture network at the site, which greatly affects site hydrology and has important implications for contaminant monitoring and remedial actions. The fracture network includes a highly transmissive zone of well-connected fractures that is intersected at $25 \mathrm{ft}$ (well 34), $92 \mathrm{ft}$ (well 59), 24-35 ft (corehole 65), and $65 \mathrm{ft}$ (corehole 71). The most direct hydraulic connection appears to be the one between the fractures at monitoring well 59 and corehole 71. The major fracture zone, which extends more than 200 $\mathrm{ft}$ across the site, is well connected, although less directly, to fractures at and below $78 \mathrm{ft}$ at corehole 65 . The poorly transmissive fracture at $76 \mathrm{ft}$ at monitoring well 58 appears to be most strongly connected to the fractures at and below $78 \mathrm{ft}$ at corehole 65 . The transmissive fractures at 19 and $45 \mathrm{ft}$ at corehole 68 appear to be only weakly connected with the fractures intersected by the other boreholes and are less connected to each other vertically than are the upper and lower fractures at coreholes 65 and 71. The transmissive fractures at corehole 72 are in hydraulic connection with the Hudson River but do not appear to be strongly connected with the fractures intersected by the other boreholes.

\section{REFERENCES CITED}

Paillet, F. L., 1998, Flow modeling and permeability estimation using borehole logs in heterogeneous fractured formations: Water Resources Research, v. 34, no. 5 , p. $997-1010$. ,2000, A field technique for estimating aquifer parameters using flow log data: Ground Water, v. 38, no. 4 , p. 510-521.

Paillet, F.L., Hess, A. E., Cheng, C. H., and Hardin, E. L., 1987, Characterization of fracture permeability with high-resolution vertical flow measurements during borehole pumping: Ground Water, v. 25, no. 1, p. 28-40.

Williams, J. H. and Johnson, C. D., 2000, Borehole-wall imaging with acoustic and optical televiewers for fractured-bedrock aquifer investigations, in Proceedings of the Seventh International Symposium on Borehole Geophysics for Minerals, Geotechnical, and Groundwater Applications: October 24-26, 2000, Denver, Colo., Minerals and Geotechnical Logging Society, p. 43-53. 